\title{
Assessment of Sulfate Radical-Based Advanced Oxidation Processes for Water and Wastewater Treatment: A Review
}

\author{
Sonia Guerra-Rodríguez ${ }^{1}$, Encarnación Rodríguez ${ }^{1}$, Devendra Narain Singh ${ }^{2}$ and \\ Jorge Rodríguez-Chueca ${ }^{1, * \mathbb{D}}$ \\ 1 Department of Industrial Chemical \& Environmental Engineering, Escuela Técnica Superior de Ingenieros \\ Industriales, Universidad Politécnica de Madrid, Calle José Gutiérrez Abascal 2, 28006 Madrid, Spain; \\ guerrarodriguezs@gmail.com (S.G.-R.); encarnacion.rodriguez@upm.es (E.R.) \\ 2 Department of Civil Engineering, Indian Institute of Technology Bombay, Powai, Mumbai 400076, India; \\ dns@civil.iitb.ac.in \\ * Correspondence: jorge.rodriguez.chueca@upm.es; Tel.: +34-910-677-334
}

Received: 16 November 2018; Accepted: 6 December 2018; Published: 11 December 2018

\begin{abstract}
High oxidation potential as well as other advantages over other tertiary wastewater treatments have led in recent years to a focus on the development of advanced oxidation processes based on sulfate radicals (SR-AOPs). These radicals can be generated from peroxymonosulfate (PMS) and persulfate (PS) through various activation methods such as catalytic, radiation or thermal activation. This review manuscript aims to provide a state-of-the-art overview of the different methods for PS and PMS activaton, as well as the different applications of this technology in the field of water and wastewater treatment. Although its most widespread application is the elimination of micropollutants, its use for the disinfection of wastewater is gaining increasing interest. In addition, the possibility of combining this technology with ultrafiltration membranes to improve the water quality and lifespan of the membranes has also been discussed. Finally, a brief economic analysis of this technology has been undertaken and the different attempts made to implement it at full-scale have been summarized. As a result, this review tries to be useful for all those people working in that area.
\end{abstract}

Keywords: advanced oxidation processes; disinfection; micropollutants; organic matter sulfate radicals; tertiary wastewater treatment

\section{Introduction}

In recent decades, industrialization and population growth have caused a significant increase in water consumption and contamination. This supposes a decrease in the water quality and the amount of available hydric resources, so that by 2030, the world is projected to face a $40 \%$ global water deficit [1]. The regeneration and reuse of wastewater could be a serious alternative to reducing the hydric stress in some regions [2]. For this purpose, water quality must obey the specifications indicated in the corresponding regulations or guidelines depending the final use of reclaimed water. Normally, water from the secondary treatment in wastewater treatment plants (WWTP) does not achieve these specifications, and advanced treatment is required, also known as tertiary treatment [3]. The variety of tertiary treatments is wide, depending of the final required quality of water and the target pollutants to remove. For instance, some examples are sedimentation, coagulation/flocculation, membrane technologies, biological filters, ionic exchange, adsorption, chemical oxidation, etc. [3].

Regulations or guidelines on the regeneration and reuse of wastewater establish maximum admissible values for different physical-chemical (suspended solids, turbidity, organic matter, 
metals, etc.) and biological (pathogen microorganisms) parameters regarding the final use of reclaimed water. The main risk in the reuse of treated wastewater comes from the presence of pathogen microorganisms. These pathogens are already responsible for waterborne diseases causing thousands of deaths every year around the world [4].

For that, disinfection is a vital process for the removal of microorganisms, pathogenic or not, and, so far, chlorination is the most common disinfectant process to this end [5]. Although chlorination is considered as an ideal disinfectant process because of it obeys almost all the conditions to be considered as that [6], it presents some important disadvantages as the formation of potentially dangerous disinfection by-products (DBPs) such as trihalomethanes (THMs) and haloacetic acids (HAAs) [7]. This generation is produced due to the reaction of chlorine and natural organic matter. Many THMs have been identified as genotoxic mutagens that can be toxic to aquatic life, and even to humans, some of them being considered as carcinogenic [8,9]. For this reason, during the last decades, the scientific community has focused on the search for disinfection alternatives [10,11]. Among them are the advanced oxidation processes (AOPs) [11-14].

Moreover, the increase of human activities along with the development of more sensitive technologies for the determination of pollutants, have led to an increase in the detection of emerging pollutants (EP). The presence of EP in water bodies has revealed a worldwide problem [15]. These compounds are defined by Geissen et al. as synthetic or naturally occurring chemicals that are not commonly monitored in the environment, but they have the potential to enter the environment and cause known or suspected adverse ecological and (or) human health effects [16]. EP can come from various sources such as, for instance, pharmaceutical active compounds and personal care products. Currently, there is no specific EP regulation anywhere in the world [17], but there are some attempts to compile a priority list. One of them, compiled by the Joint Research Centre of the European Commission, which contains more than 2700 substances [18].

In the majority of cases, EPs can be detected in WWTP effluent [15,17]. These substances are usually present in wastewater at very low concentrations (ppb or ppt) and current treatments are not designed to appropriately remove them. For this reason, it is imperative to keep developing effective technologies that can remove refractory compounds and EP [19]. Again, AOPs have proved to be a good alternative for emerging pollutant removal, although more research is still needed (especially on full-scale implementation) [20].

AOPs are based on the in situ generation of strongly reactive free radicals [21] which are capable of inactivating microorganisms and to oxidize complex organic molecules, partially or totally mineralize them $[22,23]$. AOPs occur in two steps: in situ formation of radicals and their reaction with organic or biological pollutants [21]. These technologies are based on the use of a broad range of photocatalysts, $\mathrm{TiO}_{2}$ being the most used, or the combination of oxidants such as hydrogen peroxide, peroxymonosulfate or persulfate with metal catalysts or ultraviolet (UV) radiation [24]. AOPs based on the generation of hydroxyl radicals are the most deliberated treatments. The hydroxyl radical has a higher oxidation potential $(2.8 \mathrm{~V})$ than common disinfectant agents as chlorine, ozone or permanganate as can be observed in Table $1[23,25]$. In recent years, sulfate radicals have attracted attention. These radicals could play an important role because of their high oxidation potential.

Table 1. Oxidation potential of commonly used oxidants [26].

\begin{tabular}{cc}
\hline Oxidant & Oxidation Potential (V) \\
\hline Fluorine $\left[\mathrm{F}_{2}\right]$ & 3.0 \\
Hydroxyl radical $[\mathrm{HO}]$ & 2.8 \\
Sulfate radical $\left[\mathrm{SO}_{4}{ }^{-}\right]$ & $2.5-3.1$ \\
Ozone $\left[\mathrm{O}_{3}\right]$ & 2.1 \\
Persulfate $\left[\mathrm{S}_{2} \mathrm{O}_{8}{ }^{2-}\right]$ & 2.1 \\
Peroxymonosulfate $\left[\mathrm{HSO}_{5}{ }^{-}\right]$ & 1.8 \\
Hydrogen peroxide $\left[\mathrm{H}_{2} \mathrm{O}_{2}\right]$ & 1.8 \\
Permanganate $\left[\mathrm{MnO}_{4}{ }^{-}\right]$ & 1.7 \\
Chlorine dioxide $\left[\mathrm{ClO}_{2}\right]$ & 1.5 \\
Chlorine $\left[\mathrm{Cl}_{2}\right]$ & 1.4 \\
\hline
\end{tabular}


One of the most studied AOPs is the Fenton's reagent and its variations, where iron species (mainly $\mathrm{Fe}^{2+}$ ) is used as catalyst and hydrogen peroxide acts as oxidant [23-26]. This technology presents some operation problems that have to be addressed [22,23]:

1. $\mathrm{H}_{2} \mathrm{O}_{2}$ instability

2. Restricted $\mathrm{pH}$ working range $(\mathrm{pH} 2-4)$

3. Generation of sludge $[19,27]$

Taking this into account, sulfate radical-based advanced oxidation processes (SR-AOPs) seems to be a good alternative as they have the same, or even higher, oxidation potential than hydroxyl radical (Table 1) and none of the aforementioned disadvantages. In fact, sulfate radicals presents numerous advantages which can be summarized as follows [22]:

1. As mentioned, $\mathrm{SO}_{4}{ }^{-}$- possesses a high oxidation potential (2.5-3.1 V) comparable or even higher than $\mathrm{OH}$.

2. Sulfate radical reacts more selectively and efficiently via electron transfer with organic compounds that contain unsaturated bonds or aromatic $\pi$ electrons. By contrast, $\mathrm{OH}$ is a non-selective radical and may also react with the diverse background constituted by hydrogen abstraction or electrophilic addition [28,29].

3. $\mathrm{SO}_{4} \cdot{ }^{-}$reacts efficiently with organic compounds over a wide $\mathrm{pH}$ range of $2-8$, reaching higher standard oxidation potential than hydroxyl radical at neutral $\mathrm{pH}$ [19].

4. The half-life of sulfate radicals is supposed to be 30-40 $\mu \mathrm{s}$, which enables $\mathrm{SO}_{4} \cdot{ }^{-}$to have more stable mass transfer and better contact with target compounds than hydroxyl radicals, whose half-life is $20 \mathrm{~ns}$ [30].

Given the above information, the interest on SR-AOPs has increased sharply [30-33] as can be deduced from the strong growth of the number of publications concerning this issue, which has been depicted in Figure 1, according to the information gathered from the database of Scopus. The number of publications concerning photo-Fenton (which can be considered as the treatment that most directly competes with SR-AOPs because of their similarity) has also continued to grow, but this growth follows a lineal tend, while the number of publications concerning SR-AOPs has increased exponentially, surpassing that of photo-Fenton since 2016.

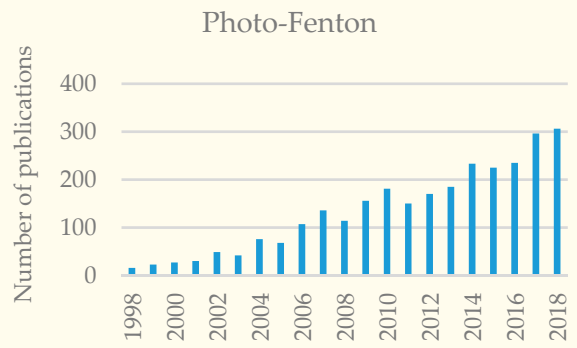

(a)

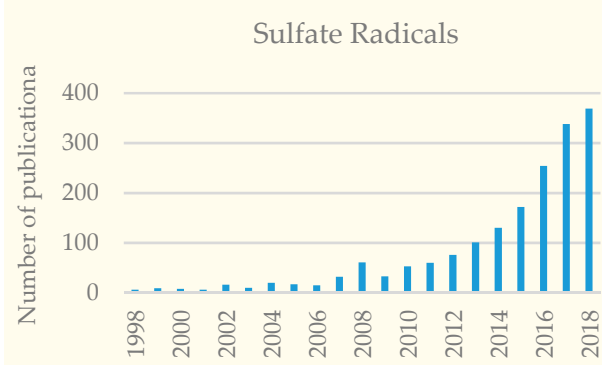

(b)

Figure 1. Number of papers published on (a) photo-Fenton and (b) sulfate radicals (applicated to advanced oxidation) on the database Scopus.

Sulfate radicals are usually generated from peroxymonosulfate (PMS) and persulfate (PS). As shown in Table 1, PMS and PS have significant oxidation potentials (1.82 and 2.1 V respectively). However, direct reaction with contaminants takes place at a very low rate so they must be activated to generate sulfate radicals [29]. PMS and PS activation can occur by various methods such as heat, UV, ultrasound or heterogeneous and homogeneous catalysis [26,32]. Nevertheless, combination of two or more different methods has been widely studied to increase the efficiency [34-36]. 
The main goal of this chapter is to analyse and compare the various activation methods of PS and PMS, and to show the advances during the last years in the use of sulfate radicals-based AOPs, especially in disinfection and removal of micropollutants present in water and wastewater.

\section{Chemistry of Peroxymonosulfate (PMS) and Persulfate (PS)}

PMS $\left(\mathrm{HSO}_{5}{ }^{-}\right)$is a white powder that can be easily dissolved in water (solubility $>250 \mathrm{~g} / \mathrm{L}$ ). It has unsymmetrical structure and the distance of the O-O bond is $1.453 \AA$ [26]. PMS is typically commercialized as Oxone ${ }^{\circledR}$ (Sigma-Aldrich), which is a triple potassium salt $\left(2 \mathrm{KHSO}_{5} \cdot \mathrm{KHSO}_{4} \cdot \mathrm{K}_{2} \mathrm{SO}_{4}\right)$. The main disadvantage of Oxone ${ }^{\circledR}$ is that it has two "dead" sulfate salts in its structure which cannot be activated [32]; nevertheless, PMS activation does not only involve a sulfate radical, but also a hydroxyl radical is generated. More chemical properties are listed in Table 2.

On the contrary, PS is a symmetric oxidant that can be found as sodium and potassium salts. These salts form white crystals which have high solubility and stability [26]. In this case, the O-O bond length is $1.497 \AA$; this value is higher than that for PMS, which symbolises a lower O-O bond dissociation energy $\left(140 \mathrm{~kJ} \cdot \mathrm{mol}^{-1}\right)$ [32].

Table 2. Chemical properties of peroxymonosulfate (PMS) and persulfate (PS).

\begin{tabular}{ccc}
\hline & PMS & PS \\
\hline Formula & $\mathrm{HSO}_{5}^{-}$ & \\
Structure & $>250$ & 192.12 \\
Molecular weight $\left[\mathrm{g} \cdot \mathrm{mol}^{-1}\right]$ & 1.8 & 2.1 \\
Solubility in water at $25{ }^{\circ} \mathrm{C}\left[\mathrm{g} \cdot \mathrm{L}^{-1}\right]$ & $140-213[26]$ & 1.497 \\
Redox potential $(\mathrm{V})$ & 1.453 &
\end{tabular}

A study made among more than 100 articles of recent years reveals that there are several companies that distribute PMS and PS salts. As depicted in Figure 2, Sigma-Aldrich is the major supplier in both cases, followed by Aladdin. Specifically, when speaking of PMS, Sigma-Aldrich holds a market share of over $50 \%$ and markets it as Oxone ${ }^{\circledR}$, which is a registered trademark.

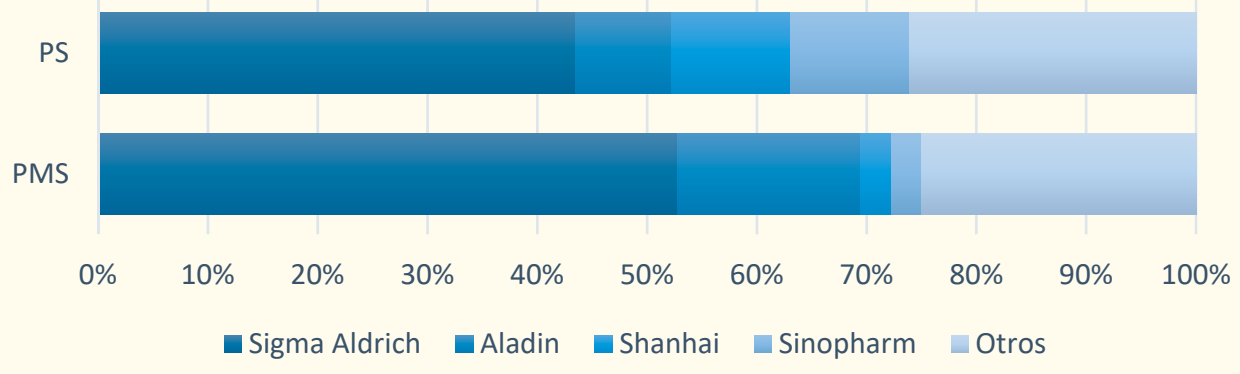

Figure 2. PMS and PS suppliers and market share. 


\section{Activation Methods and Application in Micropollutants Removal}

\subsection{Radiation Activation}

Radiation, such as ultraviolet (UV), ultrasound (US) and gamma radiation [38,39], have proved to be efficient in activating PS and PMS, albeit the use of the latter is not very extensive.

Two activation pathways might occur when using radiation. The first one is the $\mathrm{O}-\mathrm{O}$ bond fission provoked by the input of energy (Equations (1) and (2)). Furthermore, the radiation might dissociate water molecules (Equations (3)-(5)) producing the electron which activates PS and PMS by electron conduction [26].

$$
\begin{gathered}
\mathrm{S}_{2} \mathrm{O}_{8} \stackrel{-2}{\stackrel{h v}{\rightarrow}} 2 \mathrm{SO}_{4}{ }^{--} \\
\mathrm{HSO}_{5}-\stackrel{h v}{\rightarrow} \mathrm{SO}_{4}{ }^{-}+\mathrm{OH}^{\cdot} \\
\mathrm{H}_{2} \mathrm{O} \stackrel{h v}{\rightarrow} \mathrm{H}^{\cdot}+\mathrm{OH}^{\cdot} \\
\mathrm{S}_{2} \mathrm{O}_{8}{ }^{2-}+\mathrm{H}^{\cdot} \rightarrow \mathrm{SO}_{4}{ }^{--}+\mathrm{SO}_{4}{ }^{2-}+\mathrm{H}^{+} \\
\mathrm{HSO}_{5}{ }^{-}+\mathrm{H}^{\cdot} \rightarrow \mathrm{SO}_{4}{ }^{--}+\mathrm{H}_{2} \mathrm{O}
\end{gathered}
$$

Some contaminants can be degraded to some degree using single UV if their maximum absorption occurs near the used wavelength [40], but this is uncommon. Most organic pollutants resist UV radiation, but their combinations with persulfates have demonstrated to be really efficient [40-49]. From Table 3, which listed some reports of the use of UV for sulfate radical activation, it is noted that $254 \mathrm{~nm}$ is the most commonly used wavelength, which combined with the results achieved to lead to believe that PS and PMS have their maximum absorption in the UV-C spectrum. By contrast, Wacławek et al. has determined that the best wavelength for PMS activation is $350 \mathrm{~nm}$ [50].

For different micropollutants removal, different concentrations of PS or PMS was required, as well as different contact times. However, most of them have been effectively degraded in less than an hour. Even those whose complete degradation takes longer form tetramethylammonium hydroxide (TMAH) and Bisphenol A, which can be degraded by more than $80 \%$ in 60 min $[48,51]$.

The application of ultrasound for the activation of PS and PMS is less widespread than in the case

\begin{tabular}{|c|c|c|c|c|c|}
\hline Oxidant & Contaminant & Wavelength (nm) & Operating Conditions & Efficiency & Ref. \\
\hline PS & Diatrizoate thyroxine & 254 & PS $1 \mathrm{mM}^{1} ; \mathrm{pH} 7.4 ; \mathrm{T} 21^{\circ} \mathrm{C}$ & $100 \%$ & [51] \\
\hline PS & Chloroamiphenicol & 254 & PS $0.25 \mathrm{mM}$; T $20^{\circ} \mathrm{C}$ & $100 \%(60 \mathrm{~min})$ & [41] \\
\hline PS & Methyl paraben & 254 & PS $1 \mathrm{mM} ; \mathrm{pH} 6.5 ; \mathrm{T}_{\mathrm{amb}}{ }^{2}$ & $98.9 \%(90 \mathrm{~min})$ & [40] \\
\hline PS & Haloacetonitriles & 254 & PS 1 mM; pH 6; T $25^{\circ} \mathrm{C}$ & $95 \%(10 \mathrm{~min})$ & [43] \\
\hline PS & Sulfonamides & 254 & PMS $1 \mathrm{mM} ; \mathrm{pH} 7.5 ; \mathrm{T} 25^{\circ} \mathrm{C}$ & $95 \%(15 \mathrm{~min})$ & [49] \\
\hline PS & 2,4-Di-tert-butylphenol & 254 & PS 1 mM; pH 7; T $25^{\circ} \mathrm{C}$ & $85.64 \%(30 \mathrm{~min})$ & [32] \\
\hline PS & Carbamazepine & 254 & PS 1 mM; pH 3.5-5.5; T $25^{\circ} \mathrm{C}$ & $76.2 \%(90 \mathrm{~min})$ & [57] \\
\hline PMS & Carbamazepine & 254 & PMS $1 \mathrm{mM} ; \mathrm{pH} 4.5 ; \mathrm{T} 25^{\circ} \mathrm{C}$ & $98.9 \%(90 \mathrm{~min})$ & [57] \\
\hline PMS & Anatoxin-a & $260-290$ & PMS $0.15 \mathrm{mM} ; \mathrm{pH} 6.4 ; \mathrm{T}_{\mathrm{amb}}$ & $98.6 \%(10 \mathrm{~min})$ & [58] \\
\hline PMS & Criprofloxacin & 254 & PMS 1 mM; pH 7; T $25^{\circ} \mathrm{C}$ & $97 \%(60 \mathrm{~min})$ & [46] \\
\hline
\end{tabular}
of UV radiation, although there is a greater record of its use for the generation of hydroxyl radicals from hydrogen peroxide [52-54]. It is considered a clean, safe and energy saving technology, but on its own it does not have a great effect and is expensive, which makes it unviable [55].

Table 3. Micropollutant removal by ultraviolet (UV) radiation-mediated PMS and PS activation. 
However, as shown in Table 4, its combination with PMS and PS has produced promising results in recent years. One of the advantages of these technologies is that US could cause the rapid formation and collapse of cavitation bubbles, leading to an increase of pressure and temperature. This means that the oxidant, in addition to the direct action of radiation, can be thermally activated [60]. Degradations of $>90 \%$ were achieved in less than $30 \mathrm{~min}$ operating at neutral $\mathrm{pH}$ and temperatures close to ambient for 1,1,1-trichloroethane, sulfamethazine and Naphthol Blue Black [41,61,62]. Despite this, 1,4-dioxane could not be efficiently removed after $2 \mathrm{~h}$ of treatment in similar conditions [63], hence the specific optimal conditions for the elimination of each pollutant must be determined.

Table 4. Micropollutant removal by ultrasound (US)-mediated PMS and PS activation.

\begin{tabular}{|c|c|c|c|c|c|}
\hline Oxidant & Contaminant & US Power (W) & Operating Conditions & Efficiency & Ref. \\
\hline PS & Diclofenac & 700 & PS 0.44 mM; pH 6; T $30^{\circ} \mathrm{C}$ & $97 \%(4 \mathrm{~h})$ & [54] \\
\hline PS & Naphthol Blue Black & 80 & PS 1.8 mg/L; pH 6; T $25^{\circ}$ & $93 \%$ (20 min) & [63] \\
\hline PS & 1,1,1-trichloroethane & 100 & PS $0.94 \mathrm{mM}$; pH 7; T $20{ }^{\circ} \mathrm{C}$ & $90 \%(25 \mathrm{~min})$ & [55] \\
\hline PS & Carbamazepine & 200 & PS 5 mM; pH 5; T $50^{\circ} \mathrm{C}$ & $89.4 \%(2 \mathrm{~h})$ & {$[60]$} \\
\hline PS & $\begin{array}{l}\text { 1,1,1-trichloroethane (TCA) } \\
\text { 1,4-dioxane }\end{array}$ & 100 & PS 1.5 mM; pH 7; T $15{ }^{\circ} \mathrm{C}$ & $\begin{array}{l}100 \% \text { TCA }(2 \mathrm{~h}) \\
60 \% \text { dioxane }(2 \mathrm{~h})\end{array}$ & [61] \\
\hline PMS & Sulfamethazine & 600 & PMS 1,95 mM; pH 7.5 & $97.5 \%(20 \mathrm{~min})$ & [62] \\
\hline
\end{tabular}

\subsection{Thermal Activation}

Persulfates have also been successfully activated by heat in several reports, as reflected in Table 5. This activation mechanism is equivalent to that in radiation activation: energy input can cause fission of the O-O bond in PS and PMS, resulting in sulfate and hydroxyl radicals (Equations (6) and (7)).

$$
\begin{gathered}
\mathrm{S}_{2} \mathrm{O}_{8} \stackrel{-2}{\stackrel{\text { heat }}{\rightarrow}} 2 \mathrm{SO}_{4}{ }^{--} \\
\mathrm{HSO}_{5} \stackrel{\text { heat }}{\rightarrow} \mathrm{SO}_{4}^{\cdot-}+\mathrm{OH}^{\cdot}
\end{gathered}
$$

Usually, the higher the temperature, the higher is the radical generation rate and, therefore, the faster is the pollutant's removal [64]. This correlation fits properly to the Arrhenius equation (Equation (8)) [65,66]. Moreover, the contaminant removal rate adjusts in most of the studied cases to pseudo-first order kinetics (Equation (9)) [65-67]. However, extremely high temperature does not achieve better micropollutant degradation because those conditions may lead to radical-radical reactions instead of radical-contaminant reactions due to the high radical's concentration $[63,64]$.

$$
\begin{gathered}
\ln (k)=\ln A-\frac{E_{a}}{R T} \\
-\frac{d[\text { contaminant }]}{d t}=k \times[\text { contaminant }]
\end{gathered}
$$

In addition, in the study of benzoic acid degradation, it was discovered that temperature controls, not only the PS activation rate, but also the rate and distribution of breakdown products [68].

Most of the studies carried out on the field indicate that heat activation is more effective in acidic or neutral $\mathrm{pH}$ because acidic conditions are beneficial to $\mathrm{SO}_{4} \cdot-$ generation, but its effectiveness decreases in basic $\mathrm{pH}$ [69-71]. However, the elimination of bitumen has been found to be more efficient in basic medium, which indicates that the optimal conditions depend directly on the contaminant [63]. 
Table 5. Micropollutant removal by thermal activation of PMS and PS.

\begin{tabular}{|c|c|c|c|c|c|}
\hline Oxidant & Contaminant & T Range & Operating Conditions & Efficiency & Ref. \\
\hline PS & Tetracyclines & $40-70{ }^{\circ} \mathrm{C}$ & PS 2 mM; pH 7; T $70{ }^{\circ} \mathrm{C}$ & $100 \%(30 \mathrm{~min})$ & [71] \\
\hline PS & Triclosan & $50-80{ }^{\circ} \mathrm{C}$ & PS $0.155 \mathrm{mM} ; \mathrm{T}^{\circ} \mathrm{C}$ & $100 \%(2 \mathrm{~h})$ & [61] \\
\hline PS & Naphtenic acids & $40-97^{\circ} \mathrm{C}$ & PS stoichometric dose; $\mathrm{pH} 8 ; \mathrm{T} 80^{\circ} \mathrm{C}$ & $100 \%$ & [72] \\
\hline PS & Ketoprofen & $40-70{ }^{\circ} \mathrm{C}$ & PS 2 mM; pH 7; T $70{ }^{\circ} \mathrm{C}$ & $98 \%$ (10 min) & [64] \\
\hline PS & Orange G & $20-100{ }^{\circ} \mathrm{C}$ & PS 10 mM; pH 6.8; T $90^{\circ} \mathrm{C}$ & $97 \%(1 \mathrm{~min})$ & [73] \\
\hline PS & Ciprofloxacin & $40-70{ }^{\circ} \mathrm{C}$ & PS 2 mM; pH 7; T $70{ }^{\circ} \mathrm{C}$ & $92 \%(180 \mathrm{~min})$ & [67] \\
\hline PS & Cefalexin & $50-65^{\circ} \mathrm{C}$ & PS 1.1 mM; pH 7; T $60^{\circ} \mathrm{C}$ & $90.7 \%$ (4 h) & [66] \\
\hline PS & Fluconazole & $30-60{ }^{\circ} \mathrm{C}$ & PS 20 mM; pH 5; T $60^{\circ} \mathrm{C}$ & $90 \%(4 \mathrm{~h})$ & [69] \\
\hline PS & Benzoic Acid & $22-70{ }^{\circ} \mathrm{C}$ & PS 1 mM; pH 7.5; T $70^{\circ} \mathrm{C}$ & $80 \%(90 \mathrm{~min})$ & [68] \\
\hline PS & Bitumen & $25-70^{\circ} \mathrm{C}$ & $\mathrm{r}_{\mathrm{ox}}{ }^{1} 1.28 ; \mathrm{T} 60^{\circ} \mathrm{C}$ & $33 \%$ (182 min) & [74] \\
\hline PMS & Dimethoate & $40-70{ }^{\circ} \mathrm{C}$ & PS 5 mM; T $60^{\circ} \mathrm{C}$ & $100 \%(80 \mathrm{~min})$ & [65] \\
\hline PMS & Bitumen & $25-70{ }^{\circ} \mathrm{C}$ & $\mathrm{r}_{\mathrm{ox}} 1.43 ; \mathrm{T} 60^{\circ} \mathrm{C}$ & $43 \%$ (182 $\min )$ & [73] \\
\hline
\end{tabular}

\subsection{Metal Catalyst}

Several studies have proved that PS and PMS can be efficiently activated by transition metals [34,75-77]. Metal catalyst can be classified in two groups: homogeneous catalysts (transition metal ions) and heterogeneous catalysts (i.e., metal oxides, synthetized nanomaterials, natural minerals...).

Figure 3 illustrates the activation mechanism of PS and PMS by metal catalysts, both heterogeneous and homogeneous. As in the activation methods already analyzed, PS activation gives rise to two sulfate radicals, whereas the activation of PMS gives rise to a hydroxyl and sulfate radicals. In addition, PMS has the advantage that it is capable of reacting with the oxidized metal $\left(\mathrm{M}^{\mathrm{n}+1}\right)$ giving rise to sulfur pentoxide radical $\left(\mathrm{SO}_{5}{ }^{-}\right)$, less reactive than $\mathrm{SO}_{4}{ }^{-}(1.1 \mathrm{~V}$ vs $2.5 \mathrm{~V})$ but also capable of attacking contaminants.
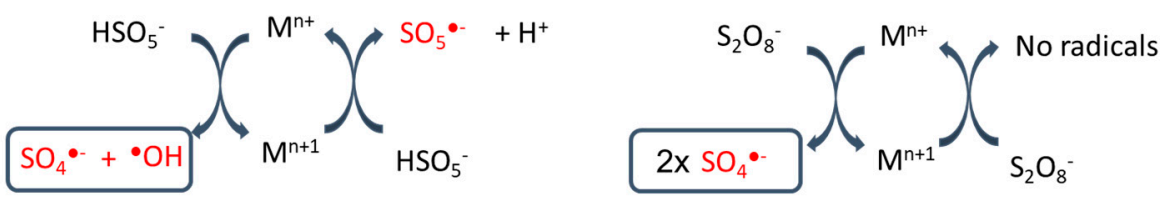

Figure 3. PMS and PS activation pathways in catalytic activation using transition metals.

Among homogeneous catalysts, Anispistakis and Dionysious determine that silver is the most efficient activator for PS and cobalt (II) for PMS [78]. Despite being slightly less efficient, iron has been the most widely studied material for this purpose, since it is environmentally friendly, relatively nontoxic and cost effective when compared with other options $[75,78,79]$. Even though satisfactory results have been obtained by homogeneous metal catalysts, this method has several drawbacks, among which the difficulty of recovering metal ions, and the consequent high concentration thereof in the treated water, stands out.

Heterogeneous catalysis presents a solution to these drawbacks since they are easier to recover, and it is not necessary to carry out subsequent treatment to remove metals from the water. Moreover, in many cases it can be reused, thus lengthening its useful life and decreasing the cost of the treatments $[80,81]$. In addition, they are much more stable under different conditions, being able to operate in a wide range of $\mathrm{pH}[37,82,83]$. For example, Bisphenol A was successfully removed with PMS activated with nickel foam-supported $\mathrm{Co}_{3} \mathrm{O}_{4}-\mathrm{Bi}_{2} \mathrm{O}_{3}(90 \%$, in $30 \mathrm{~min})$, and no important changes were observed in effectiveness when $\mathrm{pH}$ varies from 3 to 11 [82].

As the problem of the presence of toxic metal ions in product water is theoretically solved when employing heterogeneous catalysts, cobalt-based materials have been synthesized to take maximum advantage of this metal's catalytic capacities [22,82-84]. Unfortunately, several investigations have concluded that Co leaching of the catalyst can be produced in the medium $[85,86]$, so a lot of 
studies are being carried out with heterogeneous catalysts based on other metals such as iron or manganese [86-89]. Nitrobenzene degradation by PMS activated with surface minerals, reached $87 \%$ and $42 \%$ of nitrobenzene removal when using hematite and goethite (iron-based minerals) but only 15\% removal was achieved when Mn-based minerals were used [33]. Among iron-based catalysts, zero-valent iron nanoparticles have recently attracted the attention of several researchers, with the number of recently published articles being numerous [90-93]. Kang et al. compared the efficiency of nano zerovalent iron (nZVI) for 1,4-Dioxane removal when activating PS and PMS, reaching 85\% and $43 \%$ degradation respectively in $6 \mathrm{~h}$ [90].

\subsection{Carbon-Based Catalysts}

Carbon-based materials are attracting growing attention for their use as catalysts thanks to their excellent characteristics, such as their great specific surface area (SSA), their great chemical and thermal stability and the fact that there is no metal leaching and, hence no secondary contamination [28,94]. Carbon nanotubes (CNT), graphene oxide (GO), nanodiamonds (NND) and activated carbon (AC) are some of the most used structures as can be seen in Table 6. To improve the performance of the catalysts, their structure can be modified by adding other compounds, such as nitrogen or sulphur [95-98].

Activation of PMS and PS via these materials can occur through 3 different pathways: (a) radical generation (Equations (10) and (11)), (b) non-radical pathway, involving the formation of charge transfer complex, generation of singlet oxygen, and/or direct catalysis or (c) combination of both [94]. In addition, these materials usually have a strong adsorption capacity, so it is common for them to be able to eliminate a fraction of the contaminants by itself [99-101].

$$
\begin{gathered}
\mathrm{S}_{2} \mathrm{O}_{8}{ }^{-2}+e^{-} \rightarrow \mathrm{SO}_{4}{ }^{-}+\mathrm{SO}_{4}{ }^{2-} \\
\mathrm{HSO}_{5}{ }^{-}+e^{-} \rightarrow \mathrm{SO}_{4}{ }^{--}+\mathrm{OH}^{-}
\end{gathered}
$$

Some studies have tested their reusability, concluding that it is possible to reuse them up to 5 times [102], although progressively they lose efficiency [96,102,103].

The advantages of using carbon-based materials for the activation of PMS and PS are clear, but there are still some barriers to their implementation on a large scale. The complex synthesis method makes its price high and it is also necessary to better understand the activation mechanisms and study their behaviour in the presence of several pollutants at the same time, since all the reports analyse their use for the elimination of a single contaminant.

\begin{tabular}{|c|c|c|c|c|c|}
\hline Process & Contaminant & $\begin{array}{c}\text { [Catalyst] } \\
\left(\mathrm{g} \cdot \mathrm{L}^{-1}\right)\end{array}$ & Operating Conditions & Efficiency & Ref. \\
\hline PS/G-ND & phenol & 0.1 & PS 1 mM; pH 7 & $100 \%$ (10 min) & [104] \\
\hline $\mathrm{PS} /$ reduced GO & Bisphenol & 0.02 & PS $0.25 \mathrm{mM}$; pH $7 ; \mathrm{T} 25^{\circ} \mathrm{C}$ & $100 \%(30 \mathrm{~min})$ & [103] \\
\hline PS/ACS & 4-CP & 0.05 & PS $8 \mathrm{mM}$; $\mathrm{T} 25^{\circ} \mathrm{C}$ & $100 \%(60 \mathrm{~min})$ & [96] \\
\hline $\mathrm{PS} / \mathrm{NH}_{4} \mathrm{NO}_{3}-\mathrm{CNT}-\mathrm{OH}$ & 2,4,4-HBP & 0.1 & PS $21.7 \mathrm{mM}$; pH 7; T $25^{\circ} \mathrm{C}$ & $100 \%(2 \mathrm{~h})$ & [95] \\
\hline PS/CNT & Iodorganic compounds & 0.05 & PS $0.5 \mathrm{mM}$; pH 7 ; T $20^{\circ} \mathrm{C}$ & $95 \%$ (15 min) & [106] \\
\hline PS/NND & Phenol & 0.2 & PS 6.5 mM; pH 6; T $25^{\circ} \mathrm{C}$ & $90 \%$ (90 min) & [102] \\
\hline PS/AC Fiber & $\mathrm{AOG}$ & 0.3 & PS $1.76 \mathrm{mM} ; \mathrm{pH} 7 ; \mathrm{T} 25^{\circ} \mathrm{C}$ & $90 \%(2 \mathrm{~h})$ & [99] \\
\hline $\mathrm{PS} / \mathrm{NH}_{2}-\mathrm{GP}$ & SMX & 0.05 & PS 1 mM; pH 6; T $20^{\circ} \mathrm{C}$ & $50 \%(10 \mathrm{~h})$ & [103] \\
\hline PMS/NS-CNT-COOH & BP-4 & 0.1 & PMS 3.25 mM; pH 7; T $25^{\circ} \mathrm{C}$ & $100 \%$ (30 min) & [97] \\
\hline PMS/ND/GO & 4-CP & 0.1 & PMS 1 mM; pH 7 & $100 \%$ (40 min) & [107] \\
\hline PMS/CNT & Bromphenols & 50 & PMS 0.5 mM; pH 7; T $20{ }^{\circ} \mathrm{C}$ & $90 \%(60 \mathrm{~min})$ & [110] \\
\hline $\mathrm{PMS} / \mathrm{rGO}$ & Bisphenol & 0.02 & PMS 0.5 mM; pH $7 ;$ T $25^{\circ} \mathrm{C}$ & $83 \%(30 \mathrm{~min})$ & [103] \\
\hline
\end{tabular}

Table 6. PMS and PS activation though carbon-based catalysts.

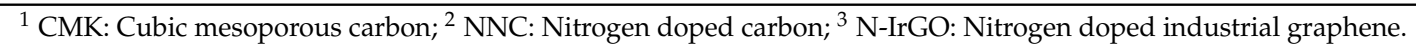




\subsection{Hybrid Activation Treatments}

Each of the activation methods mentioned has its pros and cons, so the application of two or more of them simultaneously allows the removal efficiency to be improved. Table 7 shows some examples of contaminant removal by hybrid treatments. It is very common to combine a metallic catalyst (either homogeneous or heterogeneous) with radiation, such as UV and US.

Table 7. Hybrid technology for PS and PMS activation.

\begin{tabular}{|c|c|c|c|c|}
\hline Process & Contaminant & Operating Conditions & Efficiency & Ref. \\
\hline US/PMS/nZVI & 4-Chlorophenol & pH 3; nZVI 0.4 g/L; PMS 1.25 mM & $95 \%$ (30 min) & [111] \\
\hline $\mathrm{PMS} / \mathrm{Fe} / \mathrm{UV}$ & $\mathrm{RhB}$ & $\begin{array}{l}\text { pH 5; PMS 0.6 mM; } \\
\lambda^{1}=254 \mathrm{~nm} ; \mathrm{pH} 7\end{array}$ & $100 \%(20 \mathrm{~min})$ & [112] \\
\hline $\mathrm{Fe}^{2+} /$ citrate/UV/PMS & carbamazepine & $\begin{array}{c}\mathrm{Fe}(\mathrm{II}) 12.2 \mathrm{mM} \text {; PMS } 100 \mathrm{mM} \\
\text { citrate } 26.4 \mathrm{mM}\end{array}$ & $70 \%$ (20 min) & [113] \\
\hline US/PS/UVC & Azorubine & $\mathrm{pH} 6.5 ; \mathrm{US}=1.2 \mathrm{~W} / \mathrm{cm}^{2} ; \lambda=254$ & $92 \%(10 \mathrm{~min})$ & [114] \\
\hline US/ZnO-GAC/PS & Acid Orange 7 & $\begin{array}{c}\text { PS } 0.5 \mathrm{~g} / \mathrm{L} ; \mathrm{ZnO}-\mathrm{GAC} 0.5 \mathrm{~g} / \mathrm{L} ; \\
\text { T } 30^{\circ} \mathrm{C} ; \mathrm{pH} 3 ; \mathrm{US} 60 \mathrm{~W} ;\end{array}$ & $91 \%(60 \mathrm{~min})$ & [115] \\
\hline US/nZVI/PS & Propranolol & $\begin{array}{c}\text { PS } 0.1 \text { mM; nZVI } 0.15 \mathrm{~g} / \mathrm{L} ; \\
\text { US 250W; pH } 4.5\end{array}$ & $94 \%$ (30 $\mathrm{min})$ & [116] \\
\hline $\mathrm{PMS} / \mathrm{Fe} /$ electric field & $\mathrm{C}_{9} \mathrm{H}_{20} \mathrm{ClN}$ & $\begin{array}{l}\text { PMS } 10 \mathrm{mM} \text {; pyrite } 1 \mathrm{mM} ; \\
\text { Electric field } 150 \mathrm{~mA}\end{array}$ & $80 \%$ (90 min) & [117] \\
\hline $\mathrm{US} / \mathrm{PMS} / \mathrm{Fe}_{3} \mathrm{O}_{4}$ & Acid Orange 7 & $\begin{array}{l}\text { T } 25^{\circ} \mathrm{C} ; \mathrm{pH} \text { 7.5; US 200W; } \\
\text { PMS } 3 \text { mM; } \mathrm{Fe}_{3} \mathrm{O}_{4} 0.4 \mathrm{~g} / \mathrm{L}\end{array}$ & $90 \%$ (30 min) & [118] \\
\hline
\end{tabular}

Combination of nZVI and ultrasound improved the propranol and 4-Chlorophenol degradation by more than $20 \%$ because US increased the mass transfer rate and dispersed the aggregation of nZVI $[111,116]$. Three different activators $\left(\mathrm{Fe}^{2+} /\right.$ sodium citrate/UV) have been combined for PS activation for carbamazepine removal, reaching removal efficiencies 2.6 to 5 times higher than the activation with each one of them separately [113]. The improvement implied by hybrid methods is indisputable, but a cost/benefit study must be made in each case to know if it would be viable.

\section{Sulfate Radicals Applied in Disinfection}

The effectiveness of the SR-AOPs has been proven in the elimination of organic contaminants on many occasions, but only few investigations have focused on testing their effectiveness for the inactivation of pathogenic microorganisms. However, an increasing number of reports published on the subject confirm its efficiency.

To the best of our knowledge, only the effectiveness of metallic catalysis, both heterogeneous and homogeneous, for the activation of PMS and PS in order to eliminate microorganisms from water has been analysed. Specifically, iron (in various forms and oxidation states) is the most commonly used transition metal, followed by $\mathrm{Co}^{2+}[35,119-124]$. It seems necessary to expand the number of activation methods assessed in order to choose the most effective one for full-scale implementation.

Most studies in this field are performed over strains of Escherichia coli [13,121-124]. This is because this bacterium is recognized as an indicator of faecal contamination in aquatic environments [125], and it is well known in its structure and composition. However, the inactivation of other bacteria such as S. aureus, B. mycoides, Enterococcus sp. and various fungus species has also been studied, although to a lesser extent $[119,120,126]$.

Table 8 summarizes the results of all the reports published so far about sulfate-based AOPs applied in disinfection. To calculate the effectiveness of disinfection treatments, a parameter known as disinfection rate is used, which is calculated as the logarithm of the ratio between the concentration of microorganisms at a given time and the initial concentration. A 1 log disinfection rate is equivalent to a $90 \%$ elimination of the population, while $2 \log$ equals $99 \%$ and so on.

Most of the experiments for Escherichia coli elimination have produced good results. The best results were obtained in those experiments in which a heterogeneous iron catalyst (ilmenite 
and pyrrhotite) was used, obtaining a complete disinfection in $20 \mathrm{~min}$ in both cases [120,123]. On the contrary, the combination of PMS/UV-A/ $\mathrm{Co}^{2+}$ has had a very low effect on the bacterial population [119], although these results may be due to interference in the treatment due to the composition of the wastewater used in the experiments, since the same process achieves within 60 min the complete elimination of microorganisms in other studies [124].

Table 8. Disinfection efficiencies of different sulfate radical-based advanced oxidation processes (SR-AOPs).

\begin{tabular}{|c|c|c|c|c|}
\hline Process & Microorganism & Operating Conditions & Efficiency & Ref. \\
\hline $\mathrm{PS} / \mathrm{NP}^{1}$ & E. coli & PS 1 mM; NP $1.25 \mathrm{~g} / \mathrm{L} ; \mathrm{pH} 7 ; \mathrm{T} 30^{\circ} \mathrm{C}$ & $7 \log (20 \mathrm{~min})$ & [120] \\
\hline PS/Ilmenite/vis ${ }^{2}$ & E. coli & PS 0.5 mM; Ilmenite $1 \mathrm{~g} / \mathrm{L}$ & $7 \log (20 \mathrm{~min})$ & [123] \\
\hline $\mathrm{PMS} / \mathrm{UV}-\mathrm{A} / \mathrm{Fe}^{2+}$ & E. coli & PMS 0.1 mM; $\mathrm{Fe}^{2+} 0.1 \mathrm{mM} ; \mathrm{pH} 6.5$ & $6.5 \log (30 \mathrm{~min})$ & [124] \\
\hline $\mathrm{PMS} / \mathrm{UV}-\mathrm{A} / \mathrm{Co}^{2+}$ & E. coli & PMS $0.1 \mathrm{mM} ; \mathrm{Co}^{2+} 0.1 \mathrm{mM} ; \mathrm{pH} 6.5$ & $6.5 \log (60 \mathrm{~min})$ & [124] \\
\hline $\mathrm{PS} / \mathrm{Fe}^{2+} /$ vis & E. coli & PS $150 \mathrm{mg} / \mathrm{L} ; \mathrm{Fe}^{2+} 5 \mathrm{mg} / \mathrm{L}$ & $6 \log (45 \mathrm{~min})$ & [122] \\
\hline PMS/UV-A/ $\mathrm{Fe}^{2+}$ & E. coli & PMS 0.5 mM; $\mathrm{Fe}^{2+} 0.5 \mathrm{mM} ; \mathrm{pH} 5$ & $4 \log (120 \mathrm{~min})$ & [119] \\
\hline PS $/ \mathrm{Fe}^{2+}$ & E. coli & PS 3 mM; $\mathrm{Fe}^{2+} 3$ mM; pH 7 & $3.4 \log (180 \mathrm{~min})$ & [121] \\
\hline PMS/UV-A/ $\mathrm{Co}^{2+}$ & E. coli & PMS 0.5 mM; $\mathrm{Co}^{2+} 0.5 \mathrm{mM} ;$ pH 5 & $1 \log (120 \mathrm{~min})$ & [119] \\
\hline PS/NP & S. aurous & PS 1 mM; NP $1.25 \mathrm{~g} / \mathrm{L} ; \mathrm{pH} 7 ; \mathrm{T} 30^{\circ} \mathrm{C}$ & $7 \log (20 \mathrm{~min})$ & [120] \\
\hline $\mathrm{PMS} / \mathrm{UV}-\mathrm{A} / \mathrm{Co}^{2+}$ & S. aurous & PMS 0.1 mM; $\mathrm{Co}^{2+} 0.1 \mathrm{mM}$; pH 6.5 & $6.1 \log (120 \mathrm{~min})$ & [124] \\
\hline $\mathrm{PMS} / \mathrm{UV}-\mathrm{A} / \mathrm{Co}^{2+}$ & S. aurous & PMS 0.5 mM; $\mathrm{Co}^{2+} 0.5 \mathrm{mM} ; \mathrm{pH} 5$ & $4.1 \log (120 \mathrm{~min})$ & [119] \\
\hline PMS/UV-A/Fe ${ }^{2+}$ & S. aurous & PMS 0.5 mM; $\mathrm{Fe}^{2+} 0.5 \mathrm{mM} ; \mathrm{pH} 5$ & $3.5 \log (120 \mathrm{~min})$ & [119] \\
\hline $\mathrm{PMS} / \mathrm{UV}-\mathrm{A} / \mathrm{Fe}^{2+}$ & S. aurous & PMS 0.1 mM; $\mathrm{Fe}^{2+} 0.1 \mathrm{mM} ; \mathrm{pH} 6.5$ & $3.2 \log (120 \mathrm{~min})$ & [124] \\
\hline $\mathrm{PMS} / \mathrm{UV}-\mathrm{A} / \mathrm{Co}^{2+}$ & B. mycoides & PMS 0.1 mM; $\mathrm{Co}^{2+} 0.1 \mathrm{mM} ; \mathrm{pH} 6.5$ & $3.4 \log (120 \mathrm{~min})$ & [124] \\
\hline $\mathrm{PMS} / \mathrm{UV}-\mathrm{A} / \mathrm{Fe}^{2+}$ & B. mycoides & PMS 0.5 mM; $\mathrm{Fe}^{2+} 0.5$ mM; pH 5 & $3.4 \log (120 \mathrm{~min})$ & [119] \\
\hline PMS/UV-A/Fe ${ }^{2+}$ & B. mycoides & PMS 0.1 mM; $\mathrm{Fe}^{2+} 0.1 \mathrm{mM} ; \mathrm{pH} 6.5$ & $3.2 \log (30 \mathrm{~min})$ & [124] \\
\hline $\mathrm{PMS} / \mathrm{UV}-\mathrm{A} / \mathrm{Co}^{2+}$ & B. mycoides & PMS 0.5 mM; $\mathrm{Co}^{2+} 0.5 \mathrm{mM} ; \mathrm{pH} 5$ & $3.1 \log (120 \mathrm{~min})$ & [119] \\
\hline $\mathrm{PMS} / \mathrm{UV}-\mathrm{A} / \mathrm{Co}^{2+}$ & C. albicans & PMS 5 mM; $\mathrm{Co}^{2+} 2.5 \mathrm{mM} ; \mathrm{pH} 6.5$ & $5.3 \log (30 \mathrm{~min})$ & [124] \\
\hline $\mathrm{PMS} / \mathrm{UV}-\mathrm{A} / \mathrm{Co}^{2+}$ & C. albicans & PMS 10 mM; $\mathrm{Co}^{2+} 5$ mM; pH 5 & $5 \log (120 \mathrm{~min})$ & [119] \\
\hline $\mathrm{PMS} / \mathrm{UV}-\mathrm{A} / \mathrm{Fe}^{2+}$ & C. albicans & PMS 5 mM; $\mathrm{Fe}^{2+} 2.5$ mM; pH 6.5 & $5 \log (60 \mathrm{~min})$ & [124] \\
\hline $\mathrm{PMS} / \mathrm{UV}-\mathrm{A} / \mathrm{Fe}^{2+}$ & C. albicans & PMS $10 \mathrm{mM} ; \mathrm{Fe}^{2+} 5 \mathrm{mM} ; \mathrm{pH} 5$ & $4.8 \log (120 \mathrm{~min})$ & [119] \\
\hline $\mathrm{PS} / \mathrm{Fe}^{3+} /$ vis & Enterococcus sp. & PS $5 \mathrm{mM} ; \mathrm{Fe}^{3+} 0.5 \mathrm{mM} ; \mathrm{pH} 8 ; \mathrm{T} 26^{\circ} \mathrm{C}$ & $6 \log (30 \mathrm{~min})$ & [13] \\
\hline PMS/UV-C & Acremonium sp. & PMS $0.1 \mathrm{mM} ; \mathrm{pH} 7 ; \mathrm{T} 20^{\circ} \mathrm{C}$ & $5 \log (6 \mathrm{~min})$ & [126] \\
\hline PS/UV-C & Acremonium sp. & PS 0.1 mM; pH 7; T $20^{\circ} \mathrm{C}$ & $3.7 \log (6 \mathrm{~min})$ & [126] \\
\hline PMS/UV-C & Cladosporium sp. & PMS 0.1 mM; pH 7; T $20^{\circ} \mathrm{C}$ & $4.9 \log (15 \mathrm{~min})$ & [126] \\
\hline PS/UV-C & Cladosporium sp. & PS 0.1 mM; pH 7; T $20^{\circ} \mathrm{C}$ & $3.9 \log (15 \mathrm{~min})$ & [126] \\
\hline PMS/UV-C & Penicillium sp. & PMS $0.1 \mathrm{mM} ; \mathrm{pH} 7 ; \mathrm{T} 20^{\circ} \mathrm{C}$ & $6.2 \log (9 \mathrm{~min})$ & [126] \\
\hline PS/UV-C & Penicillium sp. & PS 0.1 mM; pH 7; T $20{ }^{\circ} \mathrm{C}$ & $5.9 \log (9 \mathrm{~min})$ & [126] \\
\hline PMS/UV-C & Trichoderma sp. & PMS $0.1 \mathrm{mM} ; \mathrm{pH} 7 ; \mathrm{T} 20^{\circ} \mathrm{C}$ & $5.2 \log (6 \mathrm{~min})$ & [126] \\
\hline PS/UV-C & Trichoderma sp. & PS 0.1 mM; pH 7; T $20^{\circ} \mathrm{C}$ & $5 \log (6 \mathrm{~min})$ & [126] \\
\hline
\end{tabular}

${ }^{1} \mathrm{NP}$ : natural magnetic pyrrhotite; ${ }^{2}$ vis: visible light.

The best inactivation rate of $S$. aureus has been achieved using natural magnetic pyrrhotite (NP) as a heterogeneous catalyst [120]. Among the homogeneous catalysts, $\mathrm{Co}^{2+}$ has been the most effective activator $[119,124]$. In the case of the elimination of B. mycoides, the treatments carried out with both $\mathrm{Co}^{2+}$ and $\mathrm{Fe}^{2+}$ have provided similar results, achieving a maximum disinfection rate still far from complete disinfection $(3.4 \mathrm{log})[119,124]$.

In addition, the preliminary results of various experiments carried out by this research group, reveal that Enterococcus spp. is more resistant to disinfection treatments than E. coli. This indicates that the efficiency of the treatment is greatly affected by the cellular structure of the microorganism to be inactivated, which makes it necessary to continue studying the response of as many species as possible to the proposed treatments. Among the different iron species assessed, Fe(III)-citrate was the only one capable of activating PS and PMS for good disinfection results. This agrees with the studies carried out by Bianco et al. where a disinfection rate of $6 \log$ was achieved after $30 \mathrm{~min}$ of treatment using the couple PS/ $\mathrm{Fe}^{3+}$ together with visible light [13].

When inactivating fungal species, C. albicans has been found to be significantly more difficult to eliminate than E. coli, needing an amount of oxidant 50 times greater for its complete elimination in the same time [124]. In addition, other species such as Acremonium sp., Cladosporium sp., Penicillium sp., 
and Trichoderma sp. have been effectively eliminated using PS and PMS activated by UV-C radiation, the results obtained in PMS treatments being greater in all cases [126]. These good results are probably a consequence of the type of radiation used. Also, in addition to acting as an activator for the generation of sulfate radicals, UV-C radiation has high disinfecting power by itself.

\section{Coupling with Ultrafiltration Membrane}

The effectiveness of sulfate radical-based AOPs as tertiary treatment for micropollutants and the removal of pathogenic microorganisms has been widely analysed throughout this chapter. However, this technology can be combined with other technologies to improve the performance of certain treatments. An example of this is the application of SR-AOPs as pretreatment for ultrafiltration processes to reduce membrane fouling.

Nowadays, ultrafiltration (UF) membrane is one of the most promising and reliable alternatives for water and wastewater [127]. However, a major drawback of this technology is membrane fouling, which may lead to higher energy consumption and faster membrane degradation, reducing membrane productivity. Natural organic matter (NOM), mainly humic acids, polysaccharides, proteins, and lipids, is considered to be one of the major membrane foulants causing both reversible and irreversible membrane fouling [128].

In order to mitigate this problem, several options for the pretreatment of feed water has been put to the test, among which coagulation and adsorption are the most popular alternatives. Even if coagulation is generally considered one of the most successful pretreatments for fouling control, this method remains ineffective in the removal of some fractions in NOM [127]. AOPs have attracted greater interest in recent years due to their capacity to remove NOM, particularly when it comes to emerging organic contaminants.

There are not still many reports involving fouling mitigation with SR-AOPs, but those that exist have yielded good results. For example, $\mathrm{Fe}^{2+} / \mathrm{PMS}$ treatment have proved to significantly mitigate fouling caused by NOM, obtaining a fouling control performance slightly higher than single coagulation with the same iron dose [129]. Moreover, in another study, pretreatments with $\mathrm{Fe}^{2+} / \mathrm{PMS}^{2}$ significantly increased the efficiency by $12-76 \%$ and showed the best performance for the reduction of both reversible and irreversible fouling in comparison with coagulation and ozonation [130].

Despite great ability in mitigating fouling, $\mathrm{Fe}^{2+} / \mathrm{PS}$ and $\mathrm{Fe}^{2+} / \mathrm{PMS}$ pretreatments may produce sludge because of the formation of ferric flocs. PS and PMS can also be activated by UV radiation as an eco-friendlier method for the generation of sulfate radicals [131]. Experiments carried out using UV / PS pretreatment have achieved a significant mitigation of membrane fouling caused by NOM, reaching a decrease in dissolved organic carbon decrease to $58 \%$ and delaying irreversible membrane fouling up to $75 \%$ (within $120 \mathrm{~min}$ ) [128].

Finally, Cheng et al. have compared $\mathrm{Fe}^{2+} / \mathrm{PMS}, \mathrm{UV} / \mathrm{PMS}$, and UV $/ \mathrm{Fe}^{2+} / \mathrm{PMS}$ pretreatments and has determined that the removal performance showed an apparent regularity of $\mathrm{UV} / \mathrm{Fe}^{2+} / \mathrm{PMS}>$ $\mathrm{Fe}^{2+} / \mathrm{PMS}>\mathrm{UV} / \mathrm{PMS}$ [129]. Moreover, while $\mathrm{Fe}^{2+} / \mathrm{PMS}$ pretreatment mitigated both reversible and irreversible membrane fouling, UV/PMS only reduced reversible fouling [127,129].

Even though a lot of research is still needed, it is of particular interest to integrate SR-AOPs pretreatment with UF membrane to control membrane fouling and ensuring a better-quality product water.

\section{Economic Cost of Sulfate Radical-Based Advanced Oxidation Processes (SR-AOPs)}

Once the effectiveness of a treatment has been proved at lab-scale and pilot-plant scale, it is crucial to make an economic study to evaluate the viability of the full-scale process.

In spite of the growing interest shown by the research community in SR-AOPs, to the best of our knowledge there are only two reports that discuss the full-scale implementation of a tertiary treatment based on sulfate radicals [132,133]. However, a few authors have done a preliminary economic study considering the estimated electrical consumption of the installation and the cost of the reagents $[74,134]$. 
A comparative study carried out in two SR-AOPs treatments involving PMS and PS concluded that the latter is cheaper when employing the same amount of product, even though it is slightly less efficient. In addition to that, the cost associated with reagents purchasing when working with PMS and PS corresponds to 95 and $87 \%$ of the total treatment cost, respectively. [74]. This agrees with the result of the economic analysis carried out by Rodríguez-Chueca et al. whose results are shown in Figure 4 [132]. In this case, the percentage over the total cost of each of the individual costs (iron, oxidant, energy consumed by the pumps and energy consumed by the UV-C lamps) is compared for PMS and PS being activated only by ultraviolet radiation or adding iron. As expected, adding Fe decreases the cost of the oxidant in total; however, even under these conditions, this value is $82.26 \%$ and $97.52 \%$ when using PS and PMS respectively. On the other hand, when comparing the cost/effectiveness ratio of the $\mathrm{H}_{2} \mathrm{O}_{2} / \mathrm{UV}-\mathrm{C}$ and PMS or PS/UV-C treatments it has been concluded that treatments involving peroxide are more efficient [132].
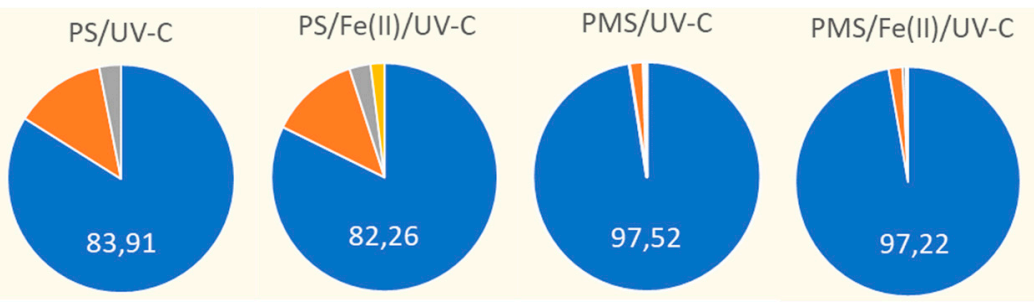

Figure 4. Cost breakdown for different SR-AOPs. " Oxidant " Iron (II) " Energy UV-C " Energy (pumps). Adapted from Rodríguez-Chueca et al [132].

At the current level of technological development, due to the amount of reagent needed and its cost, this type of treatment is not economically profitable [134]. In order to achieve the viability of full-scale installation, persulfates activation must be improved. In addition, once the technologies are well established, the large-scale production of the reagents will entail a mandatory reduction in their cost [74].

\section{Conclusions and Perspectives}

In recent years the interest generated by the application of sulphate radicals for the treatment of water and wastewater has grown, since they have a high oxidation potential. Throughout this chapter different activation methods and applications of said radicals generated from PS and PMS have been analysed.

Among the possible activation methods, metal catalysis is one of the most widespread. However, metal leaching and the consequent high concentration of ions in the product water are the main disadvantages of homogeneous catalysts. Heterogeneous catalysts appear as an alternative to avoid this, obtaining good activation results. However, for the moment it has not been possible to eliminate $100 \%$ of leaching, so it is still necessary to go deeper into the structural design to obtain more stable and efficient catalysts.

Moreover, activation by carbon-based catalysts gives very good results as a metal-free alternative. Its main advantages are that they do not leave any residue in the product water and that it is usually possible to reuse them several times before they need to be regenerated. However, its high cost and some knowledge gaps make it not so widespread. Among other things, it is necessary to improve the synthesis processes to make them cheaper and to know in depth the activation mechanisms in order to improve their structure to optimize results.

The activation methods by radiation or heat give good results in the elimination of many pollutants, but the great energy contribution they entail makes them very expensive on their own. Its combination with catalysts giving rise to hybrid activation methods enhances the effectiveness of each of the activators, obtaining better results at a lower cost. 
In addition to eliminating micropollutants, sulfate radicals can be used for disinfection. The treatment of disinfection by PS and PMS activated by transition metals promises good results in the elimination, mainly, of Escherichia coli (although some studies have also considered other species of microorganisms). However, there are very few published articles dealing with this topic and it seems necessary to study the efficiency of other activation methods, as well as their effectiveness against a wide range of microorganisms in order to confirm the effectiveness of the treatment.

The combination of SR-AOPs with other water treatment technologies is also very interesting and is a field with a good future projection. In the case of its combination with ultrafiltration treatments, a pretreatment with sulfate radicals has been shown to improve the efficiency of the process, as well as to extend the lifespan of the membranes.

Regarding the cost, although there are few analyses performed, it is known that the treatments with PS and PMS are more expensive than other advanced oxidation processes due to the price of the reagents. On the other hand, the large-scale implementation of SR-AOPs is virtually non-existent, so one of the necessary advances is the study of the scalability of these treatments. It is expected that the implementation of this technology will allow the necessary reagents to be reduced, making the treatments more viable.

Author Contributions: All the authors have contributed in the development of this work, S.G.-R. being in charge of the writing, with the help and supervision of E.R., D.N.S. and J.R.-C.

Funding: This study is supported by the Universidad Politécnica de Madrid through the feed project with Asian Institutions (VASIAUPM18JRC), and the project call "Ayudas a proyectos de I + D de investigadores postdoctorales" (VJIDOCUPM18JJRC).

Acknowledgments: Authors acknowledge the financial support from the Universidad Politécnica de Madrid through the seed research project with Asian Institutions (VASIAUPM18JRC). Besides Jorge Rodríguez-Chueca acknowledges Universidad Politécnica de Madrid through the research project VJIDOCUPM18JJRC.

Conflicts of Interest: The authors declare no conflict of interest.

\section{References}

1. WWAP (United Nations World Water Assessment Programme). The United Nations World Water Development Report 2015: Water for a Sustainable World; UNESCO: Paris, France, 2015.

2. Licciardello, F.; Milani, M.; Consoli, S.; Pappalardo, N.; Barbagallo, S.; Cirelli, G. Wastewater tertiary treatment options to match reuse standards in agriculture. Agric. Water Manag. 2018, 210, 232-242. [CrossRef]

3. Koshy, N.; Singh, D.N. Fly ash Zeolites for Water Treatment Applications. J. Environ. Chem. Eng. 2016, 4, 1460-1472. [CrossRef]

4. Gibson, K.E. Viral pathogens in water: Occurrence, public health impact, and available control strategies. Curr. Opin. Virol. 2014, 4, 50-57. [CrossRef] [PubMed]

5. Quintiliani, C.; Di Cristo, C.; Leoparti, A. Vulnerability assessment to trihalomethane exposure in water distribution. Water 2018, 10, 912. [CrossRef]

6. USEPA (United States Environmental Protection Agency). Alternative Disinfectants and Oxidants Guidance Manual; U.S. Environmental Protection Agency: Washington, DC, USA, 1999.

7. Richardson, S.D.; Plewa, M.J.; Wagner, E.D.; Schoeny, R.; DeMarini, D.M. Occurrence, genotoxicity, and carcinogenicity of regulated and emerging disinfection by-products in drinking water: A review and roadmap for research. Mutat. Res. 2007, 636, 178-242. [CrossRef] [PubMed]

8. Zhang, F.; Wang, Y.; Chu, Y.; Baoyou, G.; Yue, Q.; Yang, Z.; Li, Q. Reduction of organic matter and trihalomethane formation potential in reclaimed water from treated municipal wastewater by coagulation and adsorption. Chem. Eng. J. 2013, 223, 696-703. [CrossRef]

9. Mohd Zainudin, F.; Abu Hasan, H.; Sheikh Abdullah, S.R. An overview of the technology used to remove trihalomethane (THM), trihalomethane precursors, and trihalomethane formation potential (THMFP) from water and wastewater. J. Ind. Eng. Chem. 2018, 57, 1-14. [CrossRef]

10. Verma, K.; Gupta, D.; Gupta, A.B. Optimization of ozone disinfection and its effect on trihalomethanes. J. Environ. Chem. Eng. 2016, 4, 3021-3032. [CrossRef] 
11. Anipsitakis, G.P.; Tufano, T.P.; Dionysiou, D.D. Chemical and microbial decontamination of pool water using activated potassium peroxymonosulfate. Water Res. 2008, 42, 2899-2910. [CrossRef]

12. Gosselin, F.; Madeira, L.M.; Juhna, T.; Block, J.C. Drinking water and biofilm disinfection by fenton-like reaction. Water Res. 2013, 47, 5631-5638. [CrossRef]

13. Bianco, A.; Polo-López, M.I.; Fernández-Ibáñez, P.; Brigante, M.; Mailhot, G. Disinfection of water inoculated with enterococcus faecalis using solar/Fe(III)EDDS- $\mathrm{H}_{2} \mathrm{O}_{2}$ or $\mathrm{S}_{2} \mathrm{O}_{8}{ }^{2-}$ process. Water Res. 2017, 118, 249-260. [CrossRef] [PubMed]

14. Ruales-Lonfat, C.; Barona, J.F.; Sienkiewicz, A.; Vélez, J.; Benítez, L.N.; Pulgarín, C. Bacterial inactivation with iron citrate complex: A new source of dissolved iron in solar photo-fenton process at near-neutral and alkaline pH. Appl. Catal. B Environ. 2016, 180, 379-390. [CrossRef]

15. Díaz-Garduño, B.; Pintado-Herrera, M.G.; Biel-Maeso, M.; Rueda-Márques, J.J.; Lara-Martín, P.A.; Perales, J.A.; Manzano, M.A.; Garrido-Pérez, C.; Martín-Díaz, M.L. Environmental risk assessment of effluents as a whole emerging contaminant: Efficiency of alternative tertiary treatments for wastewater depuration. Water Res. 2017, 119, 136-149. [CrossRef] [PubMed]

16. Geissen, V.; Mol, H.; Klumpp, E.; Umlauf, G.; Nadal, M.; van der Ploeg, M.; van de Zee, S.E.A.T.M.; Ritsema, C.J. Emerging pollutants in the environment: A challenge for water resource management. ISWCR 2015, 3, 57-65.

17. Taheran, M.; Naghdi, M.; Brar, S.K.; Verma, M.; Surampalli, R.Y. Emerging contaminants: Here today, there tomorrow! Environ. Nanotechnol. Monit. Manag. 2018, 10, 122-126. [CrossRef]

18. Tornero, V.; Hanke, G. Potential Chemical Contaminants in the Marine Environment: An Overview of Main Contaminant Lists; EUR 28925; Publications Office of the European Union: Luxembourg, 2017; ISBN 978-92-79-77045-6.

19. Zhang, B.T.; Zhang, Y.; Teng, Y.; Fan, M. Sulfate radical and its application in decontamination technologies. Crit. Rev. Env. Sci. Technol. 2015, 45, 1756-1800. [CrossRef]

20. Rodriguez-Narvaez, O.M.; Peralta-Hernandez, J.M.; Goonetilleke, A.; Bandala, E.R. Treatment technologies for emerging contaminants in water: A review. Chem. Eng. J. 2017, 323, 361-380. [CrossRef]

21. Miklos, D.B.; Remy, C.; Jekel, M.; Linden, K.G.; Drewes, J.E.; Hübner, U. Evaluation of advanced oxidation processes for water and wastewater treatment-A critical review. Water Res. 2018, 139, 118-131. [CrossRef] [PubMed]

22. Hu, P.; Long, M. Cobalt-catalyzed sulfate radical-based advanced oxidation: A review on heterogeneous catalysts and applications. Appl. Catal. B Environ. 2016, 181, 103-117. [CrossRef]

23. Wang, N.; Zheng, T.; Zhang, G.; Wang, P. A review on Fenton-like processes for organic wastewater treatment. J. Environ. Chem. Eng. 2016, 4, 762-787. [CrossRef]

24. Machulek, A.; Oliveira, S.; Osugi, M.; Ferreira, V.; Quina, F.; Dantas, R.; Oliveira, S.; Casagrande, G.; Anaissi, F.; Silva, V.; et al. Application of Different Advanced Oxidation Processes for the Degradation of Organic Pollutants; IntechOpen: London, UK, 2013. [CrossRef]

25. Babuponnusami, A.; Muthukumar, K. A review on Fenton and improvements to the Fenton process for wastewater treatment. J. Environ. Chem. Eng. 2014, 2, 557-572. [CrossRef]

26. Wang, J.; Wang, S. Activation of persulfate (PS) and peroxymonosulfate (PMS) and application for the degradation of emerging contaminants. Chem. Eng. J. 2018, 334, 1502-1517. [CrossRef]

27. Shukla, P.; Sun, H.; Wang, S.; Ang, H.M.; Tadé, M.O. Co-SBA-15 for heterogeneous oxidation of phenol with sulfate radical for wastewater treatment. Catal. Today 2011, 175, 380-385. [CrossRef]

28. Zhao, Q.; Mao, Q.; Zhou, Y.; Wei, J.; Liu, X.; Yang, J.; Luo, L.; Zhang, J.; Chen, H.; Chen, H.; et al. Metal-free carbon materials-catalyzed sulfate radical-based advanced oxidation processes: A review on heterogeneous catalysts and applications. Chemosphere 2017, 189, 224-238. [CrossRef] [PubMed]

29. Liang, C.; Bruell, C.J. Thermally activated persulfate oxidation of trichloroethylene: Experimental investigation of reaction orders. Ind. Eng. Chem. Res. 2008, 47, 2912-2918. [CrossRef]

30. Ghanbari, F.; Moradi, M. Application of peroxymonosulfate and its activation methods for degradation of environmental organic pollutants: Review. Chem. Eng. J. 2017, 310, 41-62. [CrossRef]

31. Deng, Y.; Ezyske, C.M. Sulfate radical-advanced oxidation process (SR-AOP) for simultaneous removal of refractory organic contaminants and ammonia in landfill leachate. Water Res. 2011, 45, 6189-6194. [CrossRef]

32. Wacławek, S.; Lutze, H.V.; Grübel, K.; Padil, V.V.T.; Černík, M.; Dionysiou, D.D. Chemistry of persulfates in water and wastewater treatment: A review. Chem. Eng. J. 2017, 330, 44-62. [CrossRef] 
33. Yu, M.; Teel, A.L.; Watts, R.J. Activation of peroxymonosulfate by subsurface minerals. J. Contam. Hydrol. 2016, 191, 33-43. [CrossRef]

34. Rodríguez-Chueca, J.; Amor, C.; Silva, T.; Dionysiou, D.D.; Li puma, G.; Lucas, M.S.; Peres, J.A. Treatment of winery wastewater by sulphate radicals: $\mathrm{HSO}_{5}{ }^{-}$/transition metal/UV-A LEDs. Chem. Eng. J. 2017, 310, 473-483. [CrossRef]

35. Marjanovic, M.; Giannakis, S.; Grandjean, D.; de Alencastro, L.F.; Pulgarin, C. Effect of $\mu \mathrm{M}$ fe addition, mild heat and solar UV on sulfate radical-mediated inactivation of bacteria, viruses, and micropollutant degradation in water. Water Res. 2018, 140, 220-231. [CrossRef] [PubMed]

36. Dong, L.; Xu, T.; Chen, W.; Lu, W. Synergistic multiple active species for the photocatalytic degradation of contaminants by imidazole-modified g-C3N4 coordination with iron phthalocyanine in the presence of peroxymonosulfate. Chem. Eng. J. 2019, 357, 198-208. [CrossRef]

37. Oh, W.; Dong, Z.; Lim, T. Generation of sulfate radical through heterogeneous catalysis for organic contaminants removal: Current development, challenges and prospects. Appl. Catal. B Environ. 2016, 194, 169-201. [CrossRef]

38. Wang, S.; Wang, J. Degradation of carbamazepine by radiation-induced activation of peroxymonosulfate. Chem. Eng. J. 2018, 336, 595-601. [CrossRef]

39. Alkhuraiji, T.S.; Boukari, S.O.B.; Alfadhl, F.S. Gamma irradiation-induced complete degradation and mineralization of phenol in aqueous solution: Effects of reagent. J. Hazard. Mater. 2017, 328, 29-36. [CrossRef] [PubMed]

40. Dhaka, S.; Kumar, R.; Khan, M.A.; Paeng, K.J.; Kurade, M.B.; Kim, S.J.; Jeon, B.H. Aqueous phase degradation of methyl paraben using UV-activated persulfate method. Chem. Eng. J. 2017, 321, 11-19. [CrossRef]

41. Ghauch, A.; Baalbaki, A.; Amasha, M.; El Asmar, R.; Tantawi, O. Contribution of persulfate in UV-254nm activated systems for complete degradation of chloramphenicol antibiotic in water. Chem. Eng. J. 2017, 317, 1012-1025. [CrossRef]

42. Wang, Q.; Shao, Y.; Gao, N.; Chu, W.; Shen, X.; Lu, X.; Chen, J.; Zhu, Y. Degradation kinetics and mechanism of 2,4-di-tert-butylphenol with UV/persulfate. Chem. Eng. J. 2016, 304, 201-208. [CrossRef]

43. Hou, S.; Ling, L.; Shang, C.; Guan, Y.; Fang, J. Degradation kinetics and pathways of haloacetonitriles by the UV/persulfate process. Chem. Eng. J. 2017, 320, 478-484. [CrossRef]

44. Yang, Y.; Lu, X.; Jiang, J.; Ma, J.; Liu, G.; Cao, Y.; Liu, W.; Li, J.; Pang, S.; Kong, X.; et al. Degradation of sulfamethoxazole by $\mathrm{UV}, \mathrm{UV} / \mathrm{H}_{2} \mathrm{O}_{2}$ and $\mathrm{UV} /$ persulfate (PDS): Formation of oxidation products and effect of bicarbonate. Water Res. 2017, 118, 196-207. [CrossRef]

45. Ao, X.; Liu, W. Degradation of sulfamethoxazole by medium pressure UV and oxidants: Peroxymonosulfate, persulfate, and hydrogen peroxide. Chem. Eng. J. 2017, 313, 629-637. [CrossRef]

46. Mahdi-Ahmed, M.; Chiron, S. Ciprofloxacin oxidation by UV-C activated peroxymonosulfate in wastewater. J. Hazard. Mater. 2014, 265, 41-46. [CrossRef] [PubMed]

47. Xu, Y.; Lin, Z.; Wang, Y.; Zhang, H. The UV/peroxymonosulfate process for the mineralization of artificial sweetener sucralose. Chem. Eng. J. 2017, 317, 561-569. [CrossRef]

48. Wangc, C.; Liang, C. Oxidative degradation of TMAH solution with UV persulfate activation. Chem. Eng. J. 2014, 254, 472-478. [CrossRef]

49. Cui, C.; Jin, L.; Jiang, L.; Han, Q.; Lin, K.; Lu, S.; Zhang, D.; Cao, G. Removal of trace level amounts of twelve sulfonamides from drinking water by UV-activated PMS. Sci. Total Environ. 2016, 572, 244-251. [CrossRef] [PubMed]

50. Wacławek, S.; Grübel, K.; Černík, M. Simple spectrophotometric determination of monopersulfate. Spectrochim. Acta Part A 2015, 149, 928-933. [CrossRef] [PubMed]

51. Duan, X.; He, X.; Wang, D.; Mezyk, S.P.; Otto, S.C.; Marfil-Vega, R.; Mills, M.A.; Dionysiou, D.D. Decomposition of iodinated pharmaceuticals by UV-254 nm-assisted advanced oxidation processes. J. Hazard. Mater. 2017, 323, 489-499. [CrossRef]

52. Li, X.; Zhang, Y.; Xie, Y.; Zeng, Y.; Li, P.; Xie, T.; Wang, Y. Ultrasonic-enhanced fenton-like degradation of bisphenol A using a bio-synthesized schwertmannite catalyst. J. Hazard. Mater. 2018, 344, 689-697. [CrossRef]

53. Ayare, S.D.; Gogate, P.R. Sonocatalytic treatment of phosphonate containing industrial wastewater intensified using combined oxidation approaches. Ultrason. Sonochem. 2019, 51, 69-76. [CrossRef] 
54. Monteagudo, J.M.; El-taliawy, H.; Durán, A.; Caro, G.; Bester, K. Sono-activated persulfate oxidation of diclofenac: Degradation, kinetics, pathway and contribution of the different radicals involved. J. Hazard. Mater. 2018, 357, 457-465. [CrossRef]

55. Li, B.; Li, L.; Lin, K.; Zhang, W.; Lu, S.; Luo, Q. Removal of 1,1,1-trichloroethane from aqueous solution by a sono-activated persulfate process. Ultrason. Sonochem. 2013, 20, 855-863. [CrossRef] [PubMed]

56. Wang, Z.; Shao, Y.; Gao, N.; Lu, X.; An, N. Degradation of diethyl phthalate (DEP) by UV/persulfate: An experiment and simulation study of contributions by hydroxyl and sulfate radicals. Chemosphere 2018, 193, 602-610. [CrossRef] [PubMed]

57. Deng, J.; Shao, Y.; Gao, N.; Xia, S.; Tan, C.; Zhou, S.; Hu, X. Degradation of the antiepileptic drug carbamazepine upon different UV-based advanced oxidation processes in water. Chem. Eng. J. 2013, 222, 150-158. [CrossRef]

58. Verma, S.; Nakamura, S.; Sillanpää, M. Application of UV-C LED activated PMS for the degradation of anatoxin-a. Chem. Eng. J. 2016, 284, 122-129. [CrossRef]

59. Rodríguez-Chueca, J.; García-Cañibano, C.; Lepistö, R.J.; Encinas, Á.; Pellinen, J.; Marugán, J. Intensification of UV-C tertiary treatment: Disinfection and removal of micropollutants by sulfate radical based Advanced Oxidation Processes. J. Hazard. Mater. 2018, in press. [CrossRef]

60. Li, B.; Zhu, J. Simultaneous degradation of 1,1,1-trichloroethane and solvent stabilizer 1,4-dioxane by a sono-activated persulfate process. Chem. Eng. J. 2016, 284, 750-763. [CrossRef]

61. Wang, S.; Zhou, N. Removal of carbamazepine from aqueous solution using sono-activated persulfate process. Ultrason. Sonochem. 2016, 29, 156-162. [CrossRef]

62. Ferkous, H.; Merouani, S.; Hamdaoui, O.; Pétrier, C. Persulfate-enhanced sonochemical degradation of naphthol blue black in water: Evidence of sulfate radical formation. Ultrason. Sonochem. 2017, 34, 580-587. [CrossRef]

63. Yin, R.; Guo, W.; Wang, H.; Du, J.; Zhou, X.; Wu, Q.; Zheng, H.; Chang, J.; Ren, N. Enhanced peroxymonosulfate activation for sulfamethazine degradation by ultrasound irradiation: Performances and mechanisms. Chem. Eng. J. 2018, 335, 145-153. [CrossRef]

64. Feng, Y.; Song, Q.; Lu, W.; Liu, G. Degradation of ketoprofen by sulfate radical-based advanced oxidation processes: Kinetics, mechanisms, and effects of natural water matrices. Chemosphere 2017, 189, 643-651. [CrossRef]

65. Aimer, Y.; Benali, O.; Serrano, K.G. Study of the degradation of an organophosphorus pesticide using electrogenerated hydroxyl radicals or heat-activated persulfate. Sep. Purif. Technol. 2019, 208, 27-33. [CrossRef]

66. Qian, Y.; Xue, G.; Chen, J.; Luo, J.; Zhou, X.; Gao, P.; Wang, Q. Oxidation of cefalexin by thermally activated persulfate: Kinetics, products, and antibacterial activity change. J. Hazard. Mater. 2018, 354, 153-160. [CrossRef] [PubMed]

67. Jiang, C.; Ji, Y.; Shi, Y.; Chen, J.; Cai, T. Sulfate radical-based oxidation of fluoroquinolone antibiotics: Kinetics, mechanisms and effects of natural water matrices. Water Res. 2016, 106, 507-517. [CrossRef] [PubMed]

68. Zrinyi, N.; Pham, A.L. Oxidation of benzoic acid by heat-activated persulfate: Effect of temperature on transformation pathway and product distribution. Water Res. 2017, 120, 43-51. [CrossRef] [PubMed]

69. Yang, J.; Yang, L.; Zhang, S.; Ou, L.H.; Liu, C.B.; Zheng, L.Y.; Yang, Y.F.; Ying, G.G.; Luo, S.L. Degradation of azole fungicide fluconazole in aqueous solution by thermally activated persulfate. Chem. Eng. J. 2017, 321, 113-122. [CrossRef]

70. Gao, H.; Chen, J.; Zhang, Y.; Zhou, X. Sulfate radicals induced degradation of triclosan in thermally activated persulfate system. Chem. Eng. J. 2016, 306, 522-530. [CrossRef]

71. Ji, Y.; Shi, Y.; Dong, W.; Wen, X.; Jiang, M.; Lu, J. Thermo-activated persulfate oxidation system for tetracycline antibiotics degradation in aqueous solution. Chem. Eng. J. 2016, 298, 225-233. [CrossRef]

72. Xu, X.; Pliego, G.; Zazo, J.A.; Casas, J.A.; Rodriguez, J.J. Mineralization of naphtenic acids with thermally-activated persulfate: The important role of oxygen. J. Hazard. Mater. 2016, 318, 355-362. [CrossRef]

73. Ike, I.A.; Orbell, J.D.; Duke, M. Feasibility, mechanisms, and optimisation of organic pollutant degradation by thermally activated persulphate. Chem. Eng. Res. Des. 2018, 136, 304-314. [CrossRef]

74. Fernandes, A.; Makoś, P.; Boczkaj, G. Treatment of bitumen post oxidative effluents by sulfate radicals based advanced oxidation processes (S-AOPs) under alkaline pH conditions. J. Clean. Prod. 2018, 195, 374-384. [CrossRef] 
75. Rastogi, A.; Al-Abed, S.R.; Dionysiou, D.D. Sulfate radical-based ferrous-peroxymonosulfate oxidative system for PCBs degradation in aqueous and sediment systems. Appl. Catal. B Environ. 2009, 85, 171-179. [CrossRef]

76. Pan, X.; Yan, L.; Qu, R.; Wang, Z. Degradation of the UV-filter benzophenone-3 in aqueous solution using persulfate activated by heat, metal ions and light. Chemosphere 2018, 196, 95-104. [CrossRef] [PubMed]

77. Anipsitakis, G.P.; Dionysiou, D.D. Transition metal/UV-based advanced oxidation technologies for water decontamination. Appl. Catal. B Environ. 2004, 54, 155-163. [CrossRef]

78. Ismail, L.; Ferronato, C.; Fine, L.; Jaber, F.; Chovelon, J. Elimination of sulfaclozine from water with $\mathrm{SO}_{4}{ }^{-}$ radicals: Evaluation of different persulfate activation methods. Appl. Catal. B Environ. 2017, 201, 573-581. [CrossRef]

79. Rodriguez, S.; Vasquez, L.; Costa, D.; Romero, A.; Santos, A. Oxidation of orange G by persulfate activated by $\mathrm{Fe}(\mathrm{II}), \mathrm{Fe}(\mathrm{III})$ and zero valent iron (ZVI). Chemosphere 2014, 101, 86-92. [CrossRef] [PubMed]

80. Xie, Y.; Li, P.; Zeng, Y.; Li, X.; Xiao, Y.; Wang, Y.; Zhang, Y. Thermally treated fungal manganese oxides for bisphenol A degradation using sulfate radicals. Chem. Eng. J. 2018, 335, 728-736. [CrossRef]

81. Li, C.; Wu, J.; Peng, W.; Fang, Z.; Liu, J. Peroxymonosulfate activation for efficient sulfamethoxazole degradation by $\mathrm{Fe}_{3} \mathrm{O}_{4} / \beta-\mathrm{FeOOH}$ nanocomposites: Coexistence of radical and non-radical reactions. Chem. Eng. J. 2019, 356, 904-914. [CrossRef]

82. Hu, L.; Zhang, G.; Liu, M.; Wang, Q.; Dong, S.; Wang, P. Application of nickel foam-supported $\mathrm{Co}_{3} \mathrm{O}_{4}-\mathrm{Bi}_{2} \mathrm{O}_{3}$ as a heterogeneous catalyst for BPA removal by peroxymonosulfate activation. Sci. Total Environ. 2019, 647, 352-361. [CrossRef] [PubMed]

83. Lu, H.; Sui, M.; Yuan, B.; Wang, J.; Lu, Y. Efficient degradation of nitrobenzene by Cu-Co-Fe-LDH catalyzed peroxymonosulfate to produce hydroxyl radicals. Chem. Eng. J. 2019, 357, 140-149. [CrossRef]

84. Ding, Y.; Nie, W.; Li, W.; Chang, Q. Co-doped $\mathrm{NaBiO}_{3}$ nanosheets with surface confined co species: High catalytic activation of peroxymonosulfate and ultra-low co leaching. Chem. Eng. J. 2019, 356, 359-370. [CrossRef]

85. Oh, W.; Lim, T. Design and application of heterogeneous catalysts as peroxydisulfate activator for organics removal: An overview. Chem. Eng. J. 2019, 358, 110-133. [CrossRef]

86. Han, Z.; Li, J.; Han, X.; Ji, X.; Zhao, X. A comparative study of iron-based PAN fibrous catalysts for peroxymonosulfate activation in decomposing organic contaminants. Chem. Eng. J. 2019, 358, 176-187. [CrossRef]

87. Yang, Q.; Yang, X.; Yan, Y.; Sun, C.; Wu, H.; He, J.; Wang, D. Heterogeneous activation of peroxymonosulfate by different ferromanganese oxides for tetracycline degradation: Structure dependence and catalytic mechanism. Chem. Eng. J. 2018, 348, 263-270. [CrossRef]

88. Nie, W.; Mao, Q.; Ding, Y.; Hu, Y.; Tang, H. Highly efficient catalysis of chalcopyrite with surface bonded ferrous species for activation of peroxymonosulfate toward degradation of bisphenol A: A mechanism study. J. Hazard. Mater. 2019, 364, 59-68. [CrossRef] [PubMed]

89. Huang, Y.; Tian, X.; Nie, Y.; Yang, C.; Wang, Y. Enhanced peroxymonosulfate activation for phenol degradation over $\mathrm{MnO}_{2}$ at $\mathrm{pH}$ 3.5-9.0 via $\mathrm{Cu}$ (II) substitution. J. Hazard. Mater. 2018, 360, 303-310. [CrossRef]

90. Kang, Y.; Yoon, H.; Lee, W.; Kim, E.; Chang, Y. Comparative study of peroxide oxidants activated by nZVI: Removal of 1,4-dioxane and arsenic(III) in contaminated waters. Chem. Eng. J. 2018, 334, 2511-2519. [CrossRef]

91. Dong, H.; He, Q.; Zeng, G.; Tang, L.; Zhang, L.; Xie, Y.; Zeng, Y.; Zhao, F. Degradation of trichloroethene by nanoscale zero-valent iron (nZVI) and nZVI activated persulfate in the absence and presence of EDTA. Chem. Eng. J. 2017, 316, 410-418. [CrossRef]

92. Wei, X.; Gao, N.; Li, C.; Deng, Y.; Zhou, S.; Li, L. Zero-valent iron (ZVI) activation of persulfate (PS) for oxidation of bentazon in water. Chem. Eng. J. 2016, 285, 660-670. [CrossRef]

93. Li, H.; Wan, J.; Ma, Y.; Huang, M.; Wang, Y.; Chen, Y. New insights into the role of zero-valent iron surface oxidation layers in persulfate oxidation of dibutyl phthalate solutions. Chem. Eng. J. 2014, 250, 137-147. [CrossRef]

94. Xiao, R.; Luo, Z.; Wei, Z.; Luo, S.; Spinney, R.; Yang, W.; Dionysiou, D.D. Activation of peroxymonosulfate/ persulfate by nanomaterials for sulfate radical-based advanced oxidation technologies. Curr. Opin. Chem. Eng. 2018, 19, 51-58. [CrossRef] 
95. Pan, X.; Chen, J.; Wu, N.; Qi, Y.; Xu, X.; Ge, J.; Wang, X.; Li, C.; Qu, R.; Sharma, V.K.; et al. Degradation of aqueous 2,4,4'-trihydroxybenzophenone by persulfate activated with nitrogen doped carbonaceous materials and the formation of dimer products. Water Res. 2018, 143, 176-187. [CrossRef] [PubMed]

96. Guo, Y.; Zeng, Z.; Li, Y.; Huang, Z.; Cui, Y. In-situ sulfur-doped carbon as a metal-free catalyst for persulfate activated oxidation of aqueous organics. Catal. Today 2018, 307, 12-19. [CrossRef]

97. Liu, H.; Sun, P.; Feng, M.; Liu, H.; Yang, S.; Wang, L.; Wang, Z. Nitrogen and sulfur co-doped CNT-COOH as an efficient metal-free catalyst for the degradation of UV filter BP-4 based on sulfate radicals. Appl. Catal. B Environ. 2016, 187, 1-10. [CrossRef]

98. Liu, N.; Zhang, L.; Xue, Y.; Lv, J.; Yu, Q.; Yuan, X. Nitrogen-doped carbon material as a catalyst for the degradation of direct red23 based on persulfate oxidation. Sep. Purif. Technol. 2017, 184, 213-219. [CrossRef]

99. Chen, J.; Hong, W.; Huang, T.; Zhang, L.; Li, W.; Wang, Y. Activated carbon fiber for heterogeneous activation of persulfate: Implication for the decolorization of azo dye. Environ. Sci. Pollut. Res. 2016, 23, 18564-18574. [CrossRef] [PubMed]

100. Duan, X.; Sun, H.; Tade, M.; Wang, S. Metal-free activation of persulfate by cubic mesoporous carbons for catalytic oxidation via radical and nonradical processes. Catal. Today 2018, 307, 140-146. [CrossRef]

101. Wei, M.; Gao, L.; Li, J.; Fang, J.; Cai, W.; Li, X.; Xu, A. Activation of peroxymonosulfate by graphitic carbon nitride loaded on activated carbon for organic pollutants degradation. J. Hazard. Mater. 2016, 316, 60-68. [CrossRef]

102. Duan, X.; Su, C.; Zhou, L.; Sun, H.; Suvorova, A.; Odedairo, T.; Zhu, Z.; Shao, Z.; Wang, S. Surface controlled generation of reactive radicals from persulfate by carbocatalysis on nanodiamonds. Appl. Catal. B Environ. 2016, 194, 7-15. [CrossRef]

103. Olmez-Hanci, T.; Arslan-Alaton, I.; Gurmen, S.; Gafarli, I.; Khoei, S.; Safaltin, S.; Ozcelik, D.Y. Oxidative degradation of bisphenol A by carbocatalytic activation of persulfate and peroxymonosulfate with reduced graphene oxide. J. Hazard. Mater. 2018, 360, 141-149. [CrossRef] [PubMed]

104. Lee, H.; Kim, H.; Weon, S.; Choi, W.; Hwang, Y.S.; Seo, J.; Lee, C.; Kim, J.H. Activation of persulfates by graphitized nanodiamonds for removal of organic compounds. Environ. Sci. Technol. 2016, 50, 10134-10142. [CrossRef] [PubMed]

105. Chen, H.; Carroll, K.C. Metal-free catalysis of persulfate activation and organic-pollutant degradation by nitrogen-doped graphene and aminated graphene. Environ. Pollut. 2016, 215, 96-102. [CrossRef] [PubMed]

106. Guan, C.; Jiang, J.; Luo, C.; Pang, S.; Jiang, C.; Ma, J.; Jin, Y.; Li, J. Transformation of iodide by carbon nanotube activated peroxydisulfate and formation of iodoorganic compounds in the presence of natural organic matter. Environ. Sci. Technol. 2017, 51, 479-487. [CrossRef] [PubMed]

107. Yun, E.; Moon, G.; Lee, H.; Jeon, T.H.; Lee, C.; Choi, W.; Lee, J. Oxidation of organic pollutants by peroxymonosulfate activated with low-temperature-modified nanodiamonds: Understanding the reaction kinetics and mechanism. Appl. Catal. B Environ. 2018, 237, 432-441. [CrossRef]

108. Sun, P.; Liu, H.; Zhai, Z.; Zhang, X.; Fang, Y.; Tan, J.; Wu, J. Degradation of UV filter BP-1 with nitrogen-doped industrial graphene as a metal-free catalyst of peroxymonosulfate activation. Chem. Eng. J. 2019, 356, $262-271$. [CrossRef]

109. Chen, J.; Zhang, L.; Huang, T.; Li, W.; Wang, Y.; Wang, Z. Decolorization of azo dye by peroxymonosulfate activated by carbon nanotube: Radical versus non-radical mechanism. J. Hazard. Mater. 2016, 320, 571-580. [CrossRef] [PubMed]

110. Guan, C.; Jiang, J.; Luo, C.; Pang, S.; Yang, Y.; Wang, Z.; Ma, J.; Yu, J.; Zhao, X. Oxidation of bromophenols by carbon nanotube activated peroxymonosulfate (PMS) and formation of brominated products: Comparison to peroxydisulfate (PDS). Chem. Eng. J. 2018, 337, 40-50. [CrossRef]

111. Barzegar, G.; Jorfi, S.; Zarezade, V.; Khatebasreh, M.; Mehdipour, F.; Ghanbari, F. 4-chlorophenol degradation using ultrasound/peroxymonosulfate/nanoscale zero valent iron: Reusability, identification of degradation intermediates and potential application for real wastewater. Chemosphere 2018, 201, 370-379. [CrossRef] [PubMed]

112. Mei, W.; Li, D.; Xu, H.; Zan, J.; Sun, L.; Li, Q.; Zhang, B.; Wang, Y.; Xia, D. Effect of electronic migration of MIL-53(Fe) on the activation of peroxymonosulfate under visible light. Chem. Phys. Lett. 2018, 706, 694-701. [CrossRef] 
113. Ling, L.; Zhang, D.; Fang, J.; Fan, C.; Shang, C. A novel Fe(II)/citrate/UV/peroxymonosulfate process for micropollutant degradation: Optimization by response surface methodology and effects of water matrices. Chemosphere 2017, 184, 417-428. [CrossRef] [PubMed]

114. Chakma, S.; Praneeth, S.; Moholkar, V.S. Mechanistic investigations in sono-hybrid (ultrasound $\left./ \mathrm{Fe}^{2+} / \mathrm{UVC}^{2}\right)$ techniques of persulfate activation for degradation of azorubine. Ultrason. Sonochem. 2017, 38, 652-663. [CrossRef]

115. Liu, F.; Yi, P.; Wang, X.; Gao, H.; Zhang, H. Degradation of acid orange 7 by an ultrasound/ZnO-GAC/ persulfate process. Sep. Purif. Technol. 2018, 194, 181-187. [CrossRef]

116. Gao, Y.; Gao, N.; Wang, W.; Kang, S.; Xu, J.; Xiang, H.; Yin, D. Ultrasound-assisted heterogeneous activation of persulfate by nano zero-valent iron (nZVI) for the propranolol degradation in water. Ultrason. Sonochem. 2018, 49, 33-40. [CrossRef] [PubMed]

117. Arellano, M.; Sanromán, M.A.; Pazos, M. Electro-assisted activation of peroxymonosulfate by iron-based minerals for the degradation of 1-butyl-1-methylpyrrolidinium chloride. Sep. Purif. Technol. 2019, 208, 34-41. [CrossRef]

118. Liu, J.; Zhou, J.; Ding, Z.; Zhao, Z.; Xu, X.; Fang, Z. Ultrasound irritation enhanced heterogeneous activation of peroxymonosulfate with $\mathrm{Fe}_{3} \mathrm{O}_{4}$ for degradation of azo dye. Ultrason. Sonochem. 2017, 34, 953-959. [CrossRef] [PubMed]

119. Rodríguez-Chueca, J.; Moreira, S.I.; Lucas, M.S.; Fernandes, J.R.; Tavares, P.B.; Sampaio, A.; Peres, J.A. Disinfection of simulated and real winery wastewater using sulphate radicals: Peroxymonosulphate/ transition metal/UV-A LED oxidation. J. Clean. Prod. 2017, 149, 805-817. [CrossRef]

120. Xia, D.; Li, Y.; Huang, G.; Yin, R.; An, T.; Li, G.; Zhao, H.; Lu, A.; Wong, P.K. Activation of persulfates by natural magnetic pyrrhotite for water disinfection: Efficiency, mechanisms, and stability. Water Res. 2017, 112, 236-247. [CrossRef]

121. Wordofa, D.N.; Walker, S.L.; Liu, H. Sulfate radical-induced disinfection of pathogenic Escherichia coli O157:H7 via iron-activated persulfate. Environ. Sci. Technol. Lett. 2017, 4, 154-160. [CrossRef]

122. Garkusheva, N.; Matafonova, G.; Tsenter, I.; Beck, S.; Batoev, V.; Linden, K. Simultaneous atrazine degradation and E. coli inactivation by simulated solar photo-Fenton-like process using persulfate. J. Environ. Sci. Health. Part A Toxic. Hazard. Subst. Environ. Eng. 2017, 52, 849-855. [CrossRef]

123. Xia, D.; He, H.; Liu, H.; Wang, Y.; Zhang, Q.; Li, Y.; Lu, A.; He, C.; Wong, P.K. Persulfate-mediated catalytic and photocatalytic bacterial inactivation by magnetic natural ilmenite. Appl. Catal. B Environ. 2018, 238, 70-81. [CrossRef]

124. Rodríguez-Chueca, J.; Silva, T.; Fernandes, J.R.; Lucas, M.S.; Li Puma, G.; Peres, J.A.; Sampaio, A. Inactivation of pathogenic microorganisms in freshwater using $\mathrm{HSO}_{5}{ }^{-} / \mathrm{UV}-\mathrm{A}$ LED and $\mathrm{HSO}_{5}{ }^{-} / \mathrm{M}^{\mathrm{n}+} / \mathrm{UV}-\mathrm{A}$ LED oxidation processes. Water Res. 2017, 12, 113-123. [CrossRef]

125. APHA. Standard Methods for the Examination of Water and Wastewater, 21th ed.; Amer Public Health Assn: Washington, DC, USA, 2009.

126. Wen, G.; Xu, X.; Zhu, H.; Huang, T.; Ma, J. Inactivation of four genera of dominant fungal spores in groundwater using UV and UV/PMS: Efficiency and mechanisms. Chem. Eng. J. 2017, 328, 619-628. [CrossRef]

127. Cheng, X.; Liang, H.; Ding, A.; Zhu, X.; Tang, X.; Gan, Z.; Xing, J.; Wu, D.; Li, G. Application of $\mathrm{Fe}(\mathrm{II})$ / peroxymonosulfate for improving ultrafiltration membrane performance in surface water treatment: Comparison with coagulation and ozonation. Water Res. 2017, 124, 298-307. [CrossRef] [PubMed]

128. Tian, J.; Wu, C.; Yu, H.; Gao, S.; Li, G.; Cui, F.; Qu, F. Applying ultraviolet/persulfate (UV/PS) pre-oxidation for controlling ultrafiltration membrane fouling by natural organic matter (NOM) in surface water. Water Res. 2018, 132, 190-199. [CrossRef] [PubMed]

129. Cheng, X.; Liang, H.; Ding, A.; Tang, X.; Liu, B.; Zhu, X.; Gan, Z.; Wu, D.; Li, G. Ferrous iron/peroxymonosulfate oxidation as a pretreatment for ceramic ultrafiltration membrane: Control of natural organic matter fouling and degradation of atrazine. Water Res. 2017, 113, 32-41. [CrossRef] [PubMed]

130. Cheng, X.; Wu, D.; Liang, H.; Zhu, X.; Tang, X.; Gan, Z.; Xing, J.; Luo, X.; Li, G. Effect of sulfate radical-based oxidation pretreatments for mitigating ceramic UF membrane fouling caused by algal extracellular organic matter. Water Res. 2018, 145, 39-49. [CrossRef] 
131. Wang, Z.; Wan, Y.; Xie, P.; Zhou, A.; Ding, J.; Wang, J.; Zhang, L.; Wang, S.; Zhang, T.C. Ultraviolet/persulfate $(\mathrm{UV} / \mathrm{PS})$ pretreatment of typical natural organic matter (NOM): Variation of characteristics and control of membrane fouling. Chemosphere 2019, 214, 136-147. [CrossRef] [PubMed]

132. Rodríguez-Chueca, J.; Laski, E.; García-Cañibano, C.; Martín de Vidales, M.J.; Encinas, Á.; Kuch, B.; Marugán, J. Micropollutants removal by full-scale UV-C/sulfate radical based advanced oxidation processes. Sci. Total Environ. 2018, 630, 1216-1225. [CrossRef]

133. Rodríguez-Chueca, J.; Varella della Giustina, S.; Rocha, J.; Fernandes, T.; Pablos, C.; Encinas, Á.; Barceló, D.; Rodríguez-Mozaz, S.; Manaia, C.M.; Marugán, J. Assessment of full-scale tertiary wastewater treatment by UV-C based-AOPs: Removal or persistence of antibiotics and antibiotic resistance genes? Sci. Total Environ. 2019, 652, 1051-1061. [CrossRef]

134. Fernandes, A.; Makoś, P.; Khan, J.A.; Boczkaj, G. Pilot scale degradation study of 16 selected volatile organic compounds by hydroxyl and sulfate radical based advanced oxidation processes. J. Clean. Prod. 2019, 208, 54-64. [CrossRef]

(c) 2018 by the authors. Licensee MDPI, Basel, Switzerland. This article is an open access article distributed under the terms and conditions of the Creative Commons Attribution (CC BY) license (http:// creativecommons.org/licenses/by/4.0/). 